\title{
Molecular and cellular mechanisms of pulmonary fibrosis
}

Nevins W Todd ${ }^{1,2^{*}}$, Irina G Luzina ${ }^{1,2}$ and Sergei P Atamas ${ }^{1,2}$

\begin{abstract}
Pulmonary fibrosis is a chronic lung disease characterized by excessive accumulation of extracellular matrix (ECM) and remodeling of the lung architecture. Idiopathic pulmonary fibrosis is considered the most common and severe form of the disease, with a median survival of approximately three years and no proven effective therapy. Despite the fact that effective treatments are absent and the precise mechanisms that drive fibrosis in most patients remain incompletely understood, an extensive body of scientific literature regarding pulmonary fibrosis has accumulated over the past 35 years. In this review, we discuss three broad areas which have been explored that may be responsible for the combination of altered lung fibroblasts, loss of alveolar epithelial cells, and excessive accumulation of ECM: inflammation and immune mechanisms, oxidative stress and oxidative signaling, and procoagulant mechanisms. We discuss each of these processes separately to facilitate clarity, but certainly significant interplay will occur amongst these pathways in patients with this disease.
\end{abstract}

Keywords: Idiopathic pulmonary fibrosis, Extracellular matrix, Collagen, Fibroblasts, Epithelial cells, Inflammation, Oxidative stress, Coagulation

\section{Review Introduction}

Pulmonary fibrosis is a chronic lung disease characterized pathologically by excessive accumulation of extracellular matrix (ECM) and remodeling of the lung architecture, and additionally characterized by recognizable clinical, physiologic, and radiographic findings. Though some descriptions of fibrous diseases of the lungs can be found as early as the 5 th century BC by Hippocrates [1,2], more modern descriptions of pulmonary fibrosis occurred in the early part of the 20th century with reports by Hamman and Rich of four patients with rapidly progressive diffuse interstitial fibrosis of the lungs $[3,4]$. Although the prognosis of patients with diffuse pulmonary fibrosis is poor, it was subsequently realized that many patients did not have the extremely rapid deteriorating course that was described by Hamman and Rich. With further pathologic analysis, several distinct types of pulmonary fibrosis were described, and

\footnotetext{
* Correspondence: ntodd@medicine.umaryland.edu

'Department of Medicine, University of Maryland School of Medicine, Baltimore, MD, USA

${ }^{2}$ VA Medical Center, Baltimore, MD, USA

Full list of author information is available at the end of the article
}

the terms diffuse fibrosing alveolitis, diffuse interstitial fibrosis, and idiopathic pulmonary fibrosis (IPF) were introduced to describe a more insidious, yet still debilitating form of chronic pulmonary fibrosis [5,6]. Currently, IPF is considered the most common and severe form of pulmonary fibrosis, with a disheartening median survival of approximately three years, with no proven effective therapy, and with lung transplantation remaining the only viable intervention in end-stage disease [7].

The pathologic findings in pulmonary fibrosis (excessive accumulation of ECM and remodeling of the lung architecture) are a consequence of disturbances in two physiologically balanced processes: proliferation and apoptosis of fibroblasts, and accumulation and breakdown of ECM. When the normal balance between ECM deposition and turnover is shifted toward deposition or away from breakdown, excessive ECM accumulates. When the balance between fibroblast proliferation and apoptosis is shifted toward accelerated proliferation or slowed apoptosis, fibroblasts - the primary ECM producers - accumulate. Several possible origins of ECMproducing mesenchymal cells have been described, and have included accumulation of resident lung fibroblasts, homing and fibroblastic differentiation of bone marrow- 
derived cells such as circulating fibrocytes or monocytes [8-11], or epithelial-mesenchymal transition (EMT) [12]. Independent of the source of fibroblast expansion in the lungs (resident or systemic), it seems agreed upon that the ultimate effector cell in pulmonary fibrosis is the myofibroblast, a differentiated fibroblast which has contractile properties similar to smooth muscle cells, and which is characterized by the presence of alpha-smooth muscle actin $(\alpha-S M A)$.

In addition to altered mesenchymal cells, abnormalities of the alveolar epithelium in patients with pulmonary fibrosis have been noted from the earliest descriptions of the disease process [13,14]. Loss of normal type I alveolar epithelium and replacement by hyperplastic type II cells or bronchiolar cuboidal cells is a consistent finding in patients with IPF. In addition to these observations, more recent mechanistic studies have focused on the interplay, or cross-talk, between damaged epithelial cells and lung mesenchymal cells. This epithelial-mesenchymal interplay lends support to a key theme in pulmonary fibrosis, in which altered lung mesenchymal cells coupled with alveolar epithelial cell injury result in the accumulation of ECM and remodeling of the lung architecture.

An extensive body of scientific literature regarding pulmonary fibrosis has accumulated over the past 35 years, and Figure 1 shows the accelerating pace of research in this field over the past two decades. Although

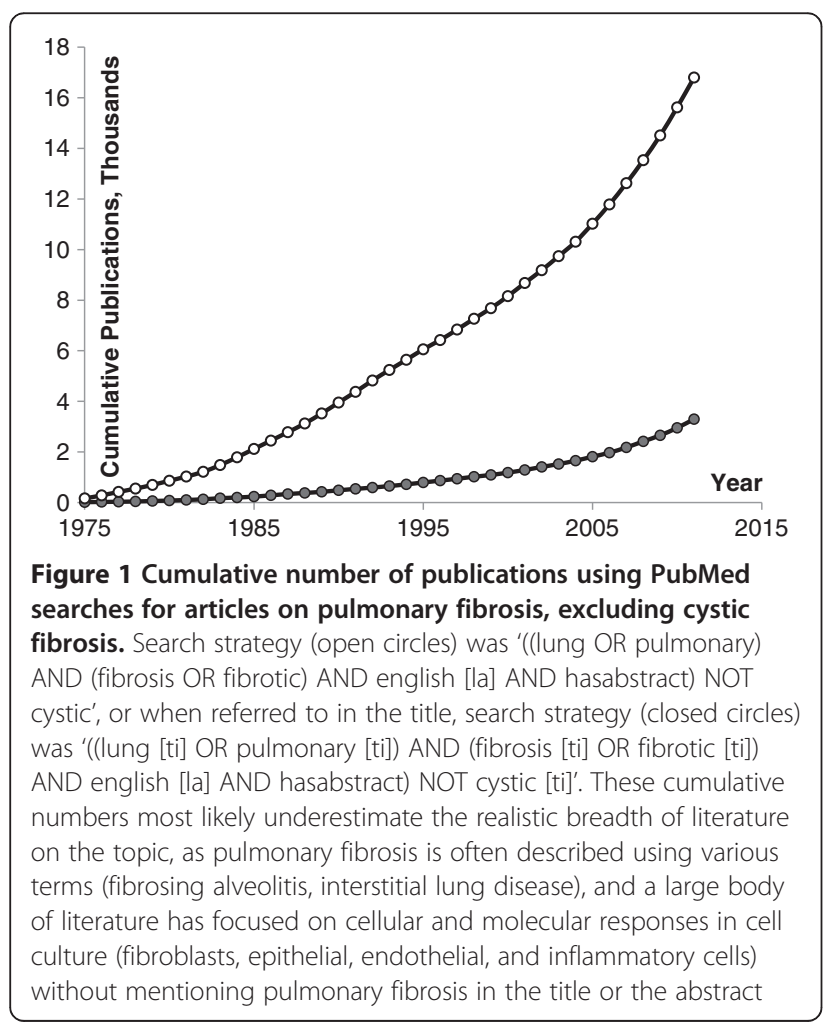

the precise mechanisms that drive the development of fibrosis in most patients remain incompletely understood, three broad areas (as seen in Figure 2) have been explored that may be responsible for the combination of altered lung fibroblasts, loss of alveolar epithelial cells, and excessive accumulation of ECM: (1) inflammation and immune mechanisms: the role of acute and chronic inflammation driven by cytokines, cells or cell surface molecules; (2) oxidative stress and oxidative signaling: the role of reactive oxygen species; and (3) a procoagulant milieu in the lung: the role of the coagulation proteinases and their tissue receptors. Each of these processes will be considered separately to facilitate clarity, but we hope the reader will appreciate the significant interplay that may occur amongst these pathways in patients with pulmonary fibrosis.

\section{Inflammation and immune mechanisms}

From the earliest descriptions of patients with pulmonary fibrosis, cellular inflammation in the lung parenchyma has been a consistent pathologic finding [3-6]. Histologic analysis has shown varied accumulations of lymphocytes, macrophages, plasma cells, eosinophils and neutrophils, and the presence of lymphoid follicles with

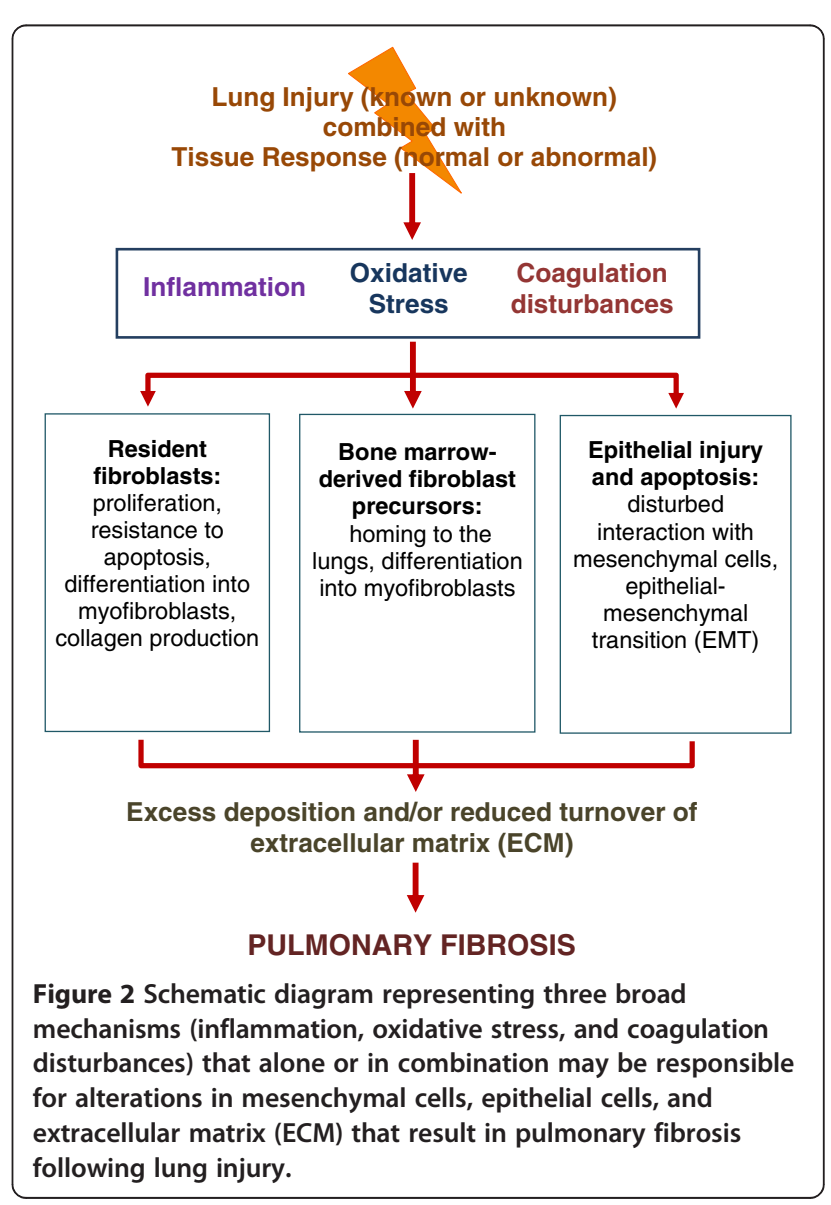


germinal centers has been observed in many patients in the lung interstitium [5,6]. The initial terms 'diffuse fibrosing alveolitis' and 'cryptogenic fibrosing alveolitis' were used as a reflection of the inflammatory component of the pathologic process in pulmonary fibrosis $[5,15]$, and most patients with usual interstitial pneumonia (UIP), the pathologic hallmark of IPF, will manifest a mild to moderate degree of chronic cellular inflammation in the lung [7,16-18].

Over the past 15 to 20 years, however, the role of inflammation has been questioned, and the hypothesis has been put forward that active cellular lung inflammation is not a major feature or requirement for the development of IPF. Recent pathologic descriptions of patients with UIP have emphasized the epithelial, mesenchymal, and ECM abnormalities while de-emphasizing the cellular inflammatory features. This paradigm has thus shifted emphasis in IPF towards a process of epithelial cell injury coupled with exaggerated wound healing, and inflammation has been relegated to a mechanistically less important and bystander role in the fibrotic process $[19,20]$. Probably the major supporting argument for inflammation playing a non-causal role stems from the observation that anti-inflammatory therapies, particularly corticosteroids, have been uniformly ineffective in improving pulmonary function or survival in patients with IPF $[21,22]$.

However, even though the role of inflammation in IPF has been recently de-emphasized, the original findings of cellular inflammation in the lung have been supplemented with an extensive accumulation of scientific studies which have implicated numerous inflammation-related cytokines and cell surface molecules in profibrotic mechanisms. It is also important to note that resistance to corticosteroids does not necessarily indicate or equate with a lack of inflammatory involvement, as there are several well-established diseases in which inflammation is clearly accepted to be the predominant underlying mechanism, but in which traditional anti-inflammatory therapy has been poorly effective [23]. Stemming from the observations on inflammatory cells, cytokines, chemokines, and cell surface molecules, the inflammation hypothesis has dominated the field of pulmonary fibrosis for nearly four decades, and IPF continues to be viewed by many authorities as a chronic inflammatory disease of the lung parenchyma [23-26].

It is difficult if not impossible to comprehensively review the evidence in support of the role of inflammation in pulmonary fibrosis. Such evidence is abundant from mechanistic studies in cell culture, experimental research in animals, and observations in human patients. Below, we provide an overview of such evidence and lines of thought, in hopes to provide a springboard for continued independent studies in the field.

\section{Role of cytokines}

Over the past 40 years of research into mechanisms of pulmonary fibrosis, an immense amount of literature has described alterations in cytokine expression and function in animals and patients with pulmonary fibrosis. Most of the findings have described a propensity for a variety of cytokines to promote and enhance the fibrotic process, whereas in some instances, up-regulation of a particular cytokine is associated with inhibition of fibrosis. In Table 1, we have listed the cytokines which we currently interpret as most relevant to mechanisms of pulmonary fibrosis, and have summarized the most pertinent in vitro, animal model, and human trial data for each cytokine. The potential sources of these cytokines in the lung are numerous, and include resident or systemic epithelial, mesenchymal, or inflammatory cells (T lymphocytes, B lymphocytes, macrophages, neutrophils, eosinophils, and platelets).

There are additional cytokines (for example, TGF- $\alpha$, IFN- $\alpha$, fibroblastic growth factor, IL-6) not included in Table 1 which have been studied in pulmonary fibrosis, but in our judgement, their regulatory role in fibrosis has been less clearly defined, and the high level of complexity of their regulation does not allow for clear designation as profibrotic or antifibrotic. Additionally, many small molecules (for example, serotonin, endothelin, leptin, lysophosphatidic acid, histamine, angiotensin) have also been studied in pulmonary fibrosis, but likewise their roles in fibrosis are less clearly defined at present.

\section{Role of inflammatory cells $T$ lymphocytes}

A consistent finding in most fibrotic diseases of the lungs is the presence of $\mathrm{T}$ lymphocytes, one of the major inflammatory cell types. Mechanistic studies regarding the role of $\mathrm{T}$ cells in pulmonary fibrosis have been performed in animals which lacked $\mathrm{T}$ lymphocytes or had selective attraction of $\mathrm{T}$ lymphocytes to the lungs. Most of these studies used bleomycin as a model of lung injury, in which fibrosis is preceded by pulmonary inflammation.

In athymic mice lacking $\mathrm{T}$ cells, administration of bleomycin resulted in less fibroblast proliferation and less ECM accumulation compared to wild-type mice [123]. Mice whose T lymphocytes lacked CD28, a central costimulatory cell surface molecule necessary for full $\mathrm{T}$ cell activation, showed markedly attenuated fibrosis following exposure to bleomycin, and transferring CD28-positive T lymphocytes into these CD28-deficient animals restored the fibrotic response to bleomycin [124]. In mice systemically depleted of $\mathrm{T}$ lymphocytes, exposure to bleomycin resulted in less collagen accumulation and increased survival compared with controls $[125,126]$. In our mouse model in which selective attraction of $\mathrm{T}$ lymphocytes to 


\section{Growth Factors}

Transforming growth factor- $\beta$ (TGF- $\beta$ )

Connective tissue growth

factor (CTGF, CCN2)

Platelet-derived growth factor (PDGF)

Insulin-like growth factor (IGF)

\section{Interleukins}

Interleukin-4 (IL-4)

Interleukin-13 (IL-13)

Interferon- $\gamma($ IFN- $\gamma)$

Interleukin-1 $\beta$ (IL-1 $\beta)$

Tumor necrosis factor-a (TNF-a)

Interleukin-17 (IL-17)

Oncostatin M (OSM)

Interleukin-10 (IL-10)

\section{Chemokines}

CCL2 (MCP-1)

CCL18 (PARC)

CCL3 (MIP-1a)

CXCL12
The major profibrotic growth factor. In vitro, stimulates fibroblast ECM production, myofibroblast differentiation, resistance to apoptosis, and production of ROS. Induces apoptosis in epithelial cells, and promotes epithelial-mesenchymal transdifferentiation (EMT). Upregulated in animal models of fibrosis, and overexpression in vivo induces severe fibrosis.

Stimulates fibroblast proliferation and ECM production in vitro. Upregulated in the bleomycin model, and overexpression in vivo induces mild fibrosis. Functions in combination with TGF- $\beta$.

Stimulates fibroblast proliferation and chemotaxis in vitro. Upregulated in animal models of fibrosis, and inhibition reduces fibrosis. Upregulated in human fibrotic diseases, but inhibition did not improve survival in patients with IPF.

Stimulates fibroblast ECM production in vitro. Upregulated in the bleomycin model, but overexpression in vivo did not induce fibrosis. Stimulates proliferation of epithelial cells.

Th-2 cytokines which stimulate fibroblast proliferation and ECM production in vitro. Upregulated in the bleomycin model, and overexpression in vivo induces fibrosis. Induce alternative activation of macrophages.

Pro-inflammatory Th-1 cytokine which inhibits fibroblast proliferation and ECM production in vitro, and enhances fibroblast apoptosis. In vivo, reduces fibrosis in the bleomycin model, but administration in patients with IPF did not improve survival.

Pro-inflammatory cytokines which in vitro stimulate fibroblast proliferation and chemotaxis, but inhibit collagen production. Upregulated in the bleomycin model, and overexpression in vivo induces inflammation and fibrosis, with fibrosis likely mediated by TGF- $\beta$. Inhibition of TNF- $\alpha$ in patients with IPF did not improve outcomes.

Pro-inflammatory cytokine which is upregulated in the bleomycin model. Exogenous administration in vivo induced fibrosis, which was reduced by blockade of TGF- $\beta$. Upregulated in patients with IPF.

In fibroblasts, stimulates proliferation and ECM production in vitro, and inhibits apoptosis. Overexpression and exogenous administration in vivo induces inflammation and fibrosis, and fibrosis occurred independently of TGF- $\beta$.

Anti-inflammatory cytokine which inhibits fibroblast ECM production in vitro, and upregulation or overexpression in the bleomycin model reduced fibrosis. In vivo overexpression alone, however, induced fibrosis, likely mediated by CCL2. Induces alternative activation of macrophages.

Pro-inflammatory CC chemokine which stimulates fibroblast ECM production and resistance to apoptosis in vitro. Upregulated in animal models of fibrosis, and in vivo loss of function (chemokine or receptor) reduces fibrosis. Recruits bone-marrow derived fibrocytes to the lung.

Pro-inflammatory CC chemokine which mildly stimulates fibroblast ECM production in vitro. Overexpression in vivo induces fibrosis, however, overexpression combined with bleomycin reduced fibrosis. Serum concentrations inversely correlated with outcomes in patients with IPF and SSc.

Pro-inflammatory CC chemokine which is upregulated in animal models of fibrosis, and in vivo loss of function (chemokine or receptor) reduces fibrosis. Recruits bone-marrow derived fibrocytes to the lung.

CXC chemokine which is upregulated in the bleomycin model, and is the major chemokines responsible for recruiting bone-marrow derived fibrocytes to the lung. Upregulated in BAL and serum in patients with IPF, and inversely correlated with physiologic parameters. the lung was achieved by over-expressing human CCL18 (PARC), a prolonged infiltration of T cells occurred, moderate collagen accumulation developed, and systemic depletion of $\mathrm{T}$ cells prevented the collagen accumulation despite the continuous expression of CCL18, suggesting that T cells were indeed the driving force of fibrosis [113]. It should be noted that although human CCL18 appears to be fully functional in mice in cell culture and in vivo [109-113, 127], the chemokine CCL18 has not been definitely identified in mice. 
There may be a complex interplay among subtypes of $\mathrm{T}$ lymphocytes in pulmonary fibrosis, particularly between $\mathrm{T}$ effector and $\mathrm{T}$ regulatory cells. $\mathrm{T}$ regulatory lymphocytes ( $\mathrm{T}$ regs) are profibrotic and immunosuppressive, and exert their profibrotic actions primarily via transforming growth factor-beta (TGF- $\beta$ ) and plateletderived growth factor (PDGF) [128]. In an animal model of silica-induced pulmonary fibrosis, $\mathrm{T}$ regs were recruited to the lungs, caused fibroblast proliferation, had increased expression of TGF- $\beta 1$ and PDGF, and caused pulmonary fibrosis upon transfer into silicaunexposed animals [45]. In silica-exposed animals depleted of $\mathrm{T}$ regs, pulmonary fibrosis occurred, but increased numbers of CD4+ $\mathrm{T}$ effectors were present. These $\mathrm{T}$ effectors caused fibroblast proliferation, caused pulmonary fibrosis upon transfer into $\mathrm{T}$ reg deficient (but not $\mathrm{T}$ reg competent) animals, and neutralizing antibody against these $\mathrm{T}$ effectors eliminated collagen accumulation [45]. These results suggest a complex interplay between lymphocyte subsets, with $\mathrm{T}$ regulatory cells themselves acting profibrotically, and the role of $\mathrm{CD} 4+\mathrm{T}$ effector cells depending on the presence or $\mathrm{ab}-$ sence of $\mathrm{T}$ regulatory cell competence.

Observational studies in humans link T cell infiltration to fibrosis. In patients with IPF, the presence of $\mathrm{T}$ cells within lung tissue and BAL of patients has been consistently observed [129-134]. These T cells are activated and antigen experienced $[132,135,136]$, and characterization has shown that both CD4+ and CD8+ cells are present, with the suggestion that CD8+ T cells represent the majority [129-132,137]. Increased numbers of CD8+ T cells in lung tissue from IPF patients was associated with worse pulmonary outcomes [130], and in BAL fluid, higher $\mathrm{CD} 4 / \mathrm{CD} 8$ ratios correlated with an improved clinical response to anti-inflammatory therapy [133]. In patients with IPF, well-organized lymph-node-like structures with features of 'lymphoid neogenesis' are present, which are composed of $\mathrm{T}$ cells expressing CD40L, B cells, and mature dendritic cells [132]. These $\mathrm{T}$ and $\mathrm{B}$ cells are activated, but not proliferating, and most are CD45RO + indicative of a memory phenotype [132]. These findings support the concept that organized lymphoid tissue can persist in the lung and contribute to chronic inflammation even in the absence of cellular proliferation.

In other forms of interstitial pneumonia, accumulation of $\mathrm{T}$ cells has been shown in BAL from patients with scleroderma [138,139], rheumatoid arthritis [140], and polymyositis/dermatomyositis [141,142]. In general, it appears that although both CD4+ and CD8+ T cells are associated with pulmonary fibrosis, CD8+ T cells appear to be associated with a worse prognosis. In patients with sarcoidosis [143], beryliosis [144], rheumatoid arthritis [140], and hypersensitivity pneumonitis [145], CD4+ T cells were predominant in the lungs, consistent with the better prognosis of these diseases compared with IPF.

Thus, there are numerous observations in animal models and in patients which describe an association of pulmonary fibrosis with $\mathrm{T}$ lymphocytic infiltration. The preponderance of evidence suggests that such association is reflective of $\mathrm{T}$ cell profibrotic action, but depending on cell phenotype and the nature of the pulmonary milieu, $\mathrm{T}$ cells may promote or diminish the pulmonary fibrotic process. Two broad mechanisms by which $\mathrm{T}$ cells may influence the fibrotic process include production of Th- 1 or Th- 2 cytokines (as seen in Table 1) and cell surface molecule interactions with epithelial or mesenchymal cells, which will be described subsequently below.

\section{Macrophages}

Macrophages constitute the majority of cells recovered from BAL of normal individuals, and have essential roles in phagocytosis, innate and adaptive immunity, and surfactant homeostasis [146]. A pathogenic role for macrophages in pulmonary fibrosis has been postulated for many years, and described mechanisms have included overexpression of reactive oxygen species [147-151], proteinase-activated receptors [152-154], Fas ligand [155], and profibrotic cytokines [97,154,156-162].

One feature regarding a potential role of macrophages in pulmonary fibrosis relates to the concept of alternative activation. Classical activation of macrophages is induced by interferon- $\gamma$, and is characterized by macrophage expression of IL-1 $\beta$, IL-6, TNF- $\alpha$, and nitric oxide. Alternative activation of macrophages is induced most notably by the Th- 2 cytokines IL- 4 and IL-13, and is characterized by macrophage expression of mannose receptor-1 (CD206), arginase-1, the lectin-binding protein Ym1, the resistin-like protein Fizz1, and the chemokine CCL18 [60,161,162].

Several animal models of pulmonary fibrosis have demonstrated that alveolar macrophages (AM) display a phenotype consistent with alternative activation. In the silica-induced model, mRNA expression of $\mathrm{Ym} 1$ in the lung increased significantly in wild-type mice consistent with alternative activation, but did not increase in silicaexposed IL-4R null mice, indicating that a Th-2 milieu was necessary for alternative activation and fibrosis [162]. In the herpes virus-induced and transgenic TGF- $\beta$ models of fibrosis, AM accumulated in the lungs and expressed the alternative activation markers $\mathrm{Ym} 1 / 2$, Fizz1 and arginase-1 [163-165].

Likewise, in patients with pulmonary fibrosis, the preponderance of data suggests that AM display an alternatively activated phenotype. In patients with IPF compared to healthy controls, AM showed increased expression of CD206, and spontaneously generated higher 
levels of the proinflammatory cytokines CCL17, CCL18, and CCL22 [97,161]. Co-culture of cell supernatants from alternatively activated AM of IPF patients with normal lung fibroblasts generated higher amounts of collagen production than supernatants from AM of healthy controls [161]. In patients with IPF, expression of arginase-1 was increased compared with healthy controls, as demonstrated by immunostaining of AM, immunostaining of lung tissue in areas of interstitial fibrosis, and by higher levels of arginase-1 protein in lung tissue lysates [163].

The above constellation of findings indicate that alternative activation of macrophages may play a mechanistic role in pulmonary fibrosis. Blocking alternative macrophage activation may prove therapeutic, and development of such new approaches to therapies for pulmonary fibrosis is under way. For example, serum amyloid P inhibited bleomycin and TGF- $\beta$ induced pulmonary fibrosis at least partially through attenuation of alternative macrophage accumulation [164,165].

\section{B lymphocytes}

Though most literature regarding potential lymphocyte involvement in mechanisms of fibrosis has referenced $\mathrm{T}$ cells, a role for B cells has been suggested for many years. As mentioned previously, patients with IPF often have well-organized lymph-node-like structures in the lung composed of activated T and B cells [132]. Production of antibody is a major function of $\mathrm{B}$ cells, and production of autoantibodies has been demonstrated against alveolar epithelial cell antigens such as vimentin and cytokeratins in patients with IPF [166-171]. Most recently, autoantibodies against periplakin, a component of desmosomes within epithelium, were identified in patients with IPF, and were associated with worse physiologic parameters [172].

A mechanistic role for B cells in pulmonary fibrosis is also supported by animal and patient data regarding CD19, a crucial cell-surface signaling molecule which is expressed on B cells and regulates $B$ cell function. In patients with systemic sclerosis (SSc), an autoimmune disease in which pulmonary fibrosis is a major cause of morbidity and mortality, systemic B cells overexpress CD19 compared to healthy controls, and polymorphisms in CD19 are associated with an increased susceptibility to SSc $[173,174]$. In an animal model of SSc, mice deficient in CD19 showed attenuated pulmonary and dermal fibrosis in response to subcutaneous bleomycin compared with wild-type controls [175]. In the intratracheal bleomycin model, overexpression of CD19 correlated with increased histologic lung fibrosis, increased lung hydroxyproline content, and reduced survival compared to wild-type controls, and mice deficient in CD19 had reduced fibrosis and improved survival compared to controls [176]. The number of B cells in BAL correlated with CD19 expression, and CD19 expression was necessary for B cell accumulation [176]. Since it has been demonstrated that the presence of CD19 alters B cell phenotype, the above results suggest that CD19 may have a mechanistic role in fibrosis by skewing B cells towards profibrotic cytokine expression.

Conversely, the presence of B cells in fibrosis may be protective. In the silica-induced model, overexpression of the anti-inflammatory cytokine IL-9 was accompanied by an expansion of B cells within the lungs and with reduced lung fibrosis $[177,178]$. The presence of $B$ cells was necessary for the protective effect of IL-9, demonstrated by lack of reduction in fibrosis in B cell-deficient mice, and by a restoration of the reduction in fibrosis by $B$ cell reconstitution [178]. The concept of conflicting roles for B cells in fibrosis is similar to that postulated for $\mathrm{T}$ cells, in which depending on cell phenotype and the nature of the pulmonary milieu, lymphocytes may promote or diminish the pulmonary fibrotic process.

\section{Fibrocytes}

Bone-marrow-derived cells that produce collagen and express markers of leukocytes (CD45) and stem cells (CD34) normally circulate at low frequencies, below $1 \%$ of circulating cells. These cells were termed fibrocytes in a seminal study [9]. In response to local and systemic injuries, including pulmonary insults, fibrocytes are released from bone marrow in higher numbers, and home to sites of injury, where they differentiate into myofibroblasts and contribute to ECM deposition $[8,9,120,121]$. Additionally, circulating monocytes may home to sites of injury and differentiate into mesenchymal cells [10,11]. Recruitment of bone-marrow-derived mesenchymal progenitors is driven by several cytokines that are produced by injured tissues, including CXCL12, CCL2, CCL3, and IL-10 [98,101,116,122]. These observations indicate that anti-fibrotic therapies should be limited not only to the organ affected by the disease, but have systemic mechanisms of action as well.

\section{Role of cell surface molecules CD40-CD40L}

CD40 ligand (CD40L or CD154) and CD40, members of the TNF family of cytokines and receptors, respectively, are cell surface molecules first identified as co-stimulatory molecules involved in the process of immune cell activation, with activated CD4+ T cells expressing CD40L, and activated antigen presenting cells expressing CD40. It was subsequently demonstrated that CD40 may also be expressed on several non-hematopoietic cell types [179], including human lung fibroblasts [180], which raised the possibility that CD40/CD40L interactions may affect fibroblast function. Subsequent work showed that engagement 
of CD40 on fibroblasts by CD40L or by agonistic antibody caused cell proliferation [61,181], mobilization of NF-kB $[179,182]$, production of IL-6 and IL-8 $[179,181,182]$, and expression of ICAM-1 and VCAM-1 [181]. Combined stimulation with IL-4, a potent stimulant for fibroblast proliferation, and ligation of CD40 had synergistic effects on enhancing fibroblast proliferation [61]. In animals, disruption of the engagement of $\mathrm{CD} 40$ by antibody against CD40L protected against radiation-induced, oxygeninduced, and autoimmune models of pulmonary injury and fibrosis [183-185].

In patients with IPF, areas of lymphocyte aggregates are often present which contain large numbers of activated T cells expressing CD40L [132]. Additional sources of CD40L include platelets, which are present in areas of lung injury due to the increased procoagulant milieu, and dendritic cells, which are present in lymphocyte aggregates in patients with IPF $[132,186,187]$. Interestingly, CD40L expression was also found in primary human fibroblasts, and found to be expressed and elevated in fibroblasts from patients with IPF compared to normal controls [188].

The constellation of findings suggests that the CD40/ CD40L system may be an important pathway by which several cell types rich in CD40L may promote and perpetuate fibrosis through engagement of CD40 on fibroblasts $[182,189]$. The finding that lung fibroblasts also express CD40L suggests that fibroblasts themselves may be able to perpetuate fibrosis in an autocrine and paracrine fashion via the CD40/CD40L pathway [188].

\section{Fas-FasL}

Fas (Fas antigen, Fas receptor, or CD95) is a member of the TNF family of cell surface receptors, is expressed in numerous cell types, and induces cellular apoptosis once engaged by FasL. FasL (Fas ligand or CD178) is a transmembrane protein belonging to the TNF family, is predominantly expressed on activated $\mathrm{T}$ lymphocytes and natural killer cells, and induces apoptosis in Fas-bearing cells. The role of the Fas-FasL pathway in pulmonary fibrosis has been examined in both epithelial and mesenchymal cells.

Bronchiolar and alveolar epithelial cell apoptosis has been a consistent finding in the bleomycin model, along with up-regulation of Fas mRNA and Fas pathway genes in epithelial cells, and up-regulation of FasL in lung tissue and infiltrating lymphocytes [190,191]. In mice, inhalation of agonistic anti-Fas antibody alone caused apoptosis of bronchiolar and alveolar epithelial cells, increased inflammation in BAL and lung tissue, increased collagen content, and increased lung tissue TGF- $\beta$ mRNA similar to that observed with bleomycin [192,193]. Inhalation or injection of soluble Fas (aimed at binding and neutralizing inherent FasL) along with bleomycin reduced epithelial cell apoptosis, tissue inflammatory cell infiltration, and collagen accumulation [194]. Mice deficient in Fas (lpr) or FasL (gld) had substantially reduced tissue inflammatory cells, epithelial cell apoptosis, and collagen accumulation compared to controls in response to bleomycin challenge [191,194]. Conversely, selective inactivation of Fas in T lymphocytes (via Cre-mediated recombination) led to upregulation of $\mathrm{T}$ cell FasL, massive infiltration of inflammatory cells in the lungs, and development of pulmonary fibrosis [195]. Treatment with neutralizing anti-FasL antibody completely prevented the accumulation of lymphocytes in the lung [195].

In mesenchymal cells, the preponderance of mechanistic data suggests inherent resistance to Fas-mediated apoptosis. In primary lung fibroblasts, ligation of cell surface Fas by agonistic antibody was unable to induce apoptosis, and resulted in increased levels of the anti-apoptotic proteins X-linked inhibitor of apoptosis (ILP) and FLICE-like inhibitor protein $\left(\right.$ FLIP $\left._{L}\right)$ [27]. Similarly, fibroblasts from patients with pulmonary fibrosis demonstrated resistance to apoptosis when exposed to recombinant FasL, and demonstrated prominent signals for ILP and FLIP $_{L}$ in lung tissue $[27,196]$. Despite inherent resistance to Fasmediated apoptosis, several studies have shown that TNF$\alpha$ and IFN- $\gamma$, particularly in combination, increase Fas expression in fibroblasts and increase susceptibility to apoptosis $[27,69,196,197]$. Attenuation of Fas expression in fibroblasts by small interfering RNA (siRNA) inhibited the ability of TNF- $\alpha$ and IFN- $\gamma$ to increase susceptibility to apoptosis, whereas transduction of fibroblasts with Fasexpressing adenovirus-enhanced apoptosis when engaged with agonistic antibody [69]. The ability of TNF- $\alpha$ and IFN- $\gamma$ to sensitize fibroblasts to apoptosis suggests that altered pro-inflammatory cytokine milieus may contribute to the development of pulmonary fibrosis.

It appears that enhanced apoptosis in epithelial cells coupled with resistance to apoptosis in mesenchymal cells affects the cross-talk between these two cell types. This altered cross-talk is often mediated by TGF- $\beta$. In the bleomycin model, myofibroblasts demonstrated overexpression of FasL and induced epithelial cell apoptosis in vitro [191]. In epithelial cells, TGF- $\beta$ induced apoptosis in vitro, and low concentrations of TGF- $\beta$, which were unable to induce epithelial cell apoptosis alone, increased apoptosis in epithelial cells stimulated with agonistic anti-Fas antibody or soluble FasL [28]. In vivo administration of TGF- $\beta$ along with agonistic anti-Fas antibody increased epithelial cell apoptosis to a degree greater than with either agent alone, and the induction of epithelial cell apoptosis by soluble FasL was inhibited by antibodies against TGF- $\beta$ [28].

Observational studies in patients with IPF have demonstrated up-regulation of Fas and Fas-signaling molecules 
in epithelial cells compared to normal controls $[69,198,199]$. Mesenchymal cells within fibroblastic foci demonstrated minimal or absent expression of Fas, and fibroblasts from patients with pulmonary fibrosis had lower expression of surface bound Fas, but higher levels of soluble Fas in the supernatant [196]. In regards to FasL, there was increased expression of soluble FasL in BAL and serum in patients with active IPF and connective tissue disease-interstitial pneumonia [198,200,201]. In lung tissue from patients with IPF, increased FasL protein was demonstrated in infiltrating granulocytes and T cells, and strong expression of FasL was seen in myofibroblasts $[191,198]$. In non-smoking patients with IPF, BAL showed increased percentages of alveolar macrophages and CD8+ cells expressing FasL along with increased levels of soluble FasL, and these findings were inversely correlated with vital capacity [155]. The summative observations in cell culture, animal models, and patients support a mechanistic role for disturbances in Fas and FasL in the development of pulmonary fibrosis.

\section{Integrins}

Integrins are heterodimeric, transmembrane cell surface molecules which primarily mediate cell-cell and cellECM adhesion, but also play major roles in cell migration, growth, and survival [202-205]. Currently, eighteen $\alpha$-subunits and eight $\beta$-subunits have been identified which associate to form 24 known integrins. Mechanistic roles for integrins in the pathogenesis of pulmonary fibrosis have been described in epithelial, inflammatory, and mesenchymal cells.

The integrin $\alpha v \beta 6$, which is expressed principally in epithelial cells, is one of the $\alpha v$-integrins which has the ability to activate latent TGF- $\beta$ by binding to the tripeptide RGD sequence on TGF- $\beta$ latency-associated peptide (LAP). In a landmark study, $\alpha v \beta 6$ activated latent TGF- $\beta$ by binding to the RGD sequence, and in the bleomycin model, mice lacking $\beta 6$ developed increased pulmonary inflammation, but were protected from pulmonary fibrosis [206]. In the animal model of radiation-induced fibrosis, $\beta 6$ was up-regulated following injury, and lack of $\beta 6$ or mutation of integrin binding site on TGF- $\beta$ LAP significantly reduced pulmonary fibrosis [207]. In the radiation-induced or bleomycin model, antibody against $\alpha v \beta 6$ reduced histologic evidence of fibrosis, hydroxyproline content, and phosphorylation of nuclear Smad 2/ $3[207,208]$. In patients with IPF, $\alpha v \beta 6$ was overexpressed within alveolar epithelial cells compared with normal controls, and in patients with systemic sclerosis, was overexpressed to a greater extent in patients with a UIP vs. NSIP pathologic pattern [208].

The integrin $\alpha v \beta 8$ is also expressed in epithelial cells and fibroblasts. In fibroblasts, $\alpha v \beta 8$ contributes to TGF- $\beta$ activation, fibrosis, and regulation of immune processes including dendritic cell function [209]. In airway epithelial cells, the $\beta 8$ subunit was highly expressed, active TGF- $\beta$ was produced, and airway proliferation was minimal [210]. Antibody against $\beta 8$ or TGF- $\beta$ reduced active TGF- $\beta$ production and resulted in enhanced airway proliferation, indicating that $\beta 8$ activation of latent TGF- $\beta$ was regulating epithelial cell proliferation. In an epithelial wounding model, administration of TGF- $\beta$ delayed wound closure, and antibody against $\alpha v \beta 8$ reduced activation of latent TGF- $\beta$ and enhanced epithelial wound closure [211]. Both of these studies suggest that activation of latent TGF- $\beta$ by $\alpha v \beta 8$ may contribute to the broad mechanism of impaired epithelial cell regeneration coupled with mesenchymal cell proliferation in patients with pulmonary fibrosis.

The integrin $\alpha 3 \beta 1$ is an epithelial cell integrin and laminin receptor. Specific loss of $\alpha 3$ expression in lung epithelial cells of mice exposed to bleomycin resulted in typical findings of acute inflammation and lung injury, but had reduced accumulation of myofibroblasts and type I collagen [212]. Specific loss of $\alpha 3$ expression resulted in an inability to form $\beta$-catenin/Smad2 complexes, a process implicated in the development of epithelial-mesenchymal transition (EMT), suggesting that the $\alpha 3 \beta 1$ integrin may play a central role in EMT [212,213].

Several integrins have been examined in inflammatory cells in pulmonary fibrosis. First, in our animal model of CCL18 overexpression, $\mathrm{T}$ lymphocytes accumulated in the lungs, expressed $\alpha v \beta 3$ and $\alpha v \beta 5$ integrins, and administration of neutralizing antibody against $\alpha v$ or genetic deficiency of $\beta 3$ significantly reduced pulmonary $\mathrm{T}$ cell infiltration and collagen accumulation [214]. Transformed T cells that overexpressed $\alpha v \beta 3$ and $\alpha v \beta 5$ stimulated collagen accumulation in co-cultured fibroblasts, which was mediated by TGF- $\beta$, and pulmonary T cells from patients with systemic sclerosis expressed $\alpha v \beta 3$ and $\alpha v \beta 5$ integrins [214]. Second, many T cells express $\alpha E \beta 7$, which is up-regulated by TGF- $\beta$, and binds to E-cadherin on epithelial cells [215]. In the bleomycin model, the majority of $\mathrm{CD} 8+$ and $\gamma \delta \mathrm{T}$ cells in BAL expressed $\alpha E \beta 7$ [216], and in patients with IPF, a significantly higher percentage of CD4+ and CD8+ T cells in BAL expressed $\alpha \mathrm{E} \beta 7$ when compared to peripheral blood [217]. Third, lymphocytes and eosinophils may express $\alpha 4$ integrin, which binds to vascular cell adhesion molecule-1 (VCAM-1) on endothelium [218]. In the bleomycin model, treatment with neutralizing antibody against $\alpha 4$ resulted in reduced cellular inflammation, lipid peroxidation, hydroxyproline content, histologic fibrosis, and $\alpha$ SMA compared with controls [219]. Though the precise role of $\mathrm{T}$ cells in the pathogenesis of pulmonary fibrosis remains incompletely understood, $\mathrm{T}$ cell expression of several integrins which bind epithelium or ECM skew 
the pulmonary milieu towards a pro- or anti-phenotype depending on the $\mathrm{T}$ cell phenotype.

Integrins expressed on fibroblasts have been shown to activate latent TGF- $\beta$ and promote fibrosis. The $\alpha 2 \beta 1$ integrin is a major type I collagen receptor [220]. In normal fibroblasts, exposure to polymerized collagen inhibited proliferation, whereas fibroblasts from patients with IPF demonstrated abnormal proliferation due to activation of the PI3K-Akt-S6K1 pathway and low activity of the tumor suppressor phosphatase and tensin homologue (PTEN) [221]. Protein expression of PTEN was preserved, but there was defective regulation of PTEN function by the $\alpha 2 \beta 1$-polymerized collagen interaction. Consistent with these in-vitro experiments, mice haploinsufficient for PTEN showed an exaggerated fibroproliferative response and increased collagen deposition in a cutaneous and bleomycin injury model, and immunohistochemistry in patients with IPF showed activation of Akt in fibroblastic foci [221].

Myofibroblast contraction has been shown to activate TGF- $\beta$ by inducing conformational changes in LAP mediated by integrin binding. Contraction of myofibroblasts along with mechanically-resistant ECM activated latent TGF- $\beta$ via $\alpha v \beta 5$ binding, and blocking antibodies against $\alpha v \beta 5$ prevented this TGF- $\beta$ activation [222]. Thy-1, a cell surface glycoprotein which inhibits a fibrogenic phenotype in fibroblasts and is associated with decreased fibrosis in the bleomycin model [223,224], may have a role in cell contraction-mediated TGF- $\beta$ activation. Several studies have shown that Thy-1 can bind to integrins, and specifically, Thy- 1 bound $\alpha v \beta 5$ in a cell-free system and on the surface of lung fibroblasts [225]. Upon exposure to cell contraction agonists, fibroblasts either lacking Thy- 1 or in which Thy-1/ $\alpha v \beta 5$ binding was prevented were able to activate latent TGF- $\beta$ and promote myofibroblast differentiation, whereas these effects were absent in fibroblasts expressing Thy-1 [225]. Thesis data suggested that Thy- 1 is able to bind $\alpha v \beta 5$ on the cell surface, and prevent myofibroblast contraction-induced integrin-dependent activation of latent TGF- $\beta$.

In patients with localized or diffuse scleroderma, fibroblasts demonstrated increased expression of $\alpha v \beta 5$, and exposure to exogenous latent TGF- $\beta$ increased collagen production [226,227]. Overexpression of $\alpha v \beta 5$ on normal fibroblasts recruited latent TGF- $\beta$ on the cell surface, increased collagen promoter activity, and resulted in differentiation to a myofibroblastic phenotype, with each of these reduced or reversed with antibody against $\alpha v \beta 5$ [226-228]. Thesis data in aggregate from patients with scleroderma showed that up-regulation of $\alpha \mathrm{v} \beta 5$ expression in fibroblasts increased ECM production and promoted myofibroblastic differentiation through enhanced autocrine TGF- $\beta$ signaling.

\section{Potential mechanistic role of inflammation} Absence of cellular infiltration does not equate with lack of inflammation

As mentioned previously, recent pathologic descriptions of patients with IPF have emphasized the epithelial, mesenchymal, and ECM abnormalities, while deemphasizing the possible contributions of inflammation to mechanisms of the disease. Most patients with IPF will manifest a mild to moderate degree of chronic cellular inflammation in the lung pathologically, but it is true that some patients with end-stage lung disease and advanced UIP on biopsy will have minimal evidence of chronic inflammatory cells in the lung parenchyma. Although infiltration with inflammatory cells is an overall common feature of inflammation, the degree of cellular infiltration may vary significantly depending on the particular tissue which is involved. In disease of tendons (tendinopathies), the presence of inflammatory cells is rather limited, due most likely to tissue architecture constraints, but an active inflammatory process is present based on levels of cytokines, growth factors, prostaglandins, and neuropeptides $[229,230]$. In the spatially confined brain, often considered an "immune-privileged" organ, cellular infiltration following injuries or autoimmune processes is minor, but the brain is fully capable of an active inflammatory response, with cytokines playing key roles [231233]. Molecular rather than cellular inflammation appears to drive the response to injury in tendons and brain, and the lack of inflammatory cells does not equate with lack of inflammation.

\section{Resistance to corticosteroids does not equate with lack of inflammation}

An additional concept that should not be equated with lack of inflammation is resistance to corticosteroids. There are several well-established diseases in which inflammation is clearly accepted to be the predominant underlying mechanism, but traditional anti-inflammatory therapy has been poorly or completely ineffective in groups or subgroups of patients [23]. Chronic obstructive pulmonary disease (COPD) is a chronic inflammatory disease of the lungs, with high levels of pro-inflammatory cells and cytokines, but most studies have shown that inhaled or systemic corticosteroids do not significantly reduce cellular or molecular markers of inflammation, and do not improve long-term lung function or survival in patients [234-241]. Asthma is also a prototypical inflammatory lung disease of the airways, and although most patients with asthma respond well to corticosteroids, a subset of patients have steroid-resistant asthma, manifested clinically by a poor response to treatment, and mechanistically by continued expression of proinflammatory and profibrotic cytokines in alveolar macrophages and $\mathrm{T}$ cells despite exposure to 
corticosteroids [242-247]. In the autoimmune inflammatory diseases rheumatoid arthritis (RA) and systemic lupus erythematosis (SLE), a subset of patients will respond poorly to corticosteroids, and mononuclear and $\mathrm{T}$ cells from these patients showed less inhibition of proliferation and less apoptosis when exposed to corticosteroids [248,249]. Similarly, a proportion of patients with inflammatory bowel disease (IBD) will have a poor or absent response to corticosteroids, and peripheral blood $\mathrm{T}$ cells from these patients showed less inhibition of proliferation when exposed to corticosteroids [250,251].

The normal mechanisms by which corticosteroids reduce inflammation have been reviewed in detail [235]. Several mechanisms have been postulated by which patients with inflammatory diseases may manifest resistance to corticosteroid therapy, and these have included abnormalities in bone morphogenetic protein receptor [252], increased phosphorylation and subsequent reduced nuclear translocation of the activated glucocorticoid receptor (GR) [253], reduced expression of the anti-inflammatory protein MKP-1 resulting from increased p38 mitogen-activated protein kinase activity [254], reduced binding affinity of GR for corticosteroids due to nitrosylation of GR by inducible nitric oxide synthase [255], or excessive activation of the transcription factor AP-1 which prevents GR interaction with DNA glucocorticoid response elements [256]. One other particularly noteworthy cause of corticosteroid-resistant inflammation in chronic lung disease results from decreased histone deacetylase activity. Corticosteroids normally reduce inflammation by decreasing transcription of activated inflammatory genes, which occurs at least in part by recruitment of histone deacetylase-2 (HDAC2) [235]. In epithelial cells, inhibition of histone deacetylase activity promoted corticosteroid resistance, and this resistance was reversed by HDAC2 overexpression [257]. Reduced levels of histone deacetylase-2 (HDAC2) have been observed in patients with COPD and refractory asthma [258,259], and one mechanism of reduced deacetylase activity is inactivation of HDAC2 by oxidative stress, which has been demonstrated in epithelial cells, animal models, and patients with COPD [260262].

Based on all the available mechanistic, animal model, and observational data regarding inflammation and immune mechanisms, it may be a reasonable conclusion that IPF is a chronic inflammatory disease of the lung, but cellular infiltration is minor compared to the substantial changes in pulmonary cytokines, and the absence of clinical improvement in treated patients may be a manifestation of resistance to conventional antiinflammatory therapies. The fact that oxidative stress has been found capable of promoting steroid-resistant inflammation is certainly a thought provoking concept, given the large amount of data demonstrating high levels of oxidative stress in patients with pulmonary fibrosis, which will be discussed below.

\section{Oxidative stress and oxidative signaling}

Molecular oxygen is central to aerobic metabolism, is critically required for vertebrates, and must be constantly supplied to ensure survival. However, oxygen is a strong oxidant, and has damaging effects on cells and biologic macromolecules due to formation of reactive oxygen species (ROS). Oxidative stress occurs when there is an imbalance between the generation of ROS and the capacity to detoxify these intermediates, which occurs when generation of ROS is excessive, antioxidant defenses are reduced, or both disturbances occur together. Additionally, extensive evidence suggests that ROS may be also involved with post-translational processing of proteins and intracellular signaling mechanisms in health and disease, including activation or deactivation of signaling factors, regulation of gene expression, and cell differentiation. Over many years, there has been accumulating evidence that oxidative stress and/or oxidative signaling may play a major role in the pathogenesis of pulmonary fibrosis [263-266].

\section{Overview of reactive oxygen species and antioxidant defenses}

Reactive oxygen species are formed by single electron reductions of molecular oxygen, leading to formation of superoxide anion $\left(\mathrm{O}_{2}^{-}\right)$, hydrogen peroxide $\left(\mathrm{H}_{2} \mathrm{O}_{2}\right)$, and the hydroxyl radical $\left({ }^{\circ} \mathrm{OH}\right)$ [267]. Due to their powerful oxidizing capability, ROS can lead to generation of advanced oxidation molecular products and induce damage to cellular and subcellular structures within the lung, including DNA, proteins, cell membranes, and mitochondria. Reactive oxygen species production may result from several sources in the lung, including the mitochondrial electron transport chain, myeloperoxidase, xanthine oxidase, and NADPH oxidases [263,266].

The enzyme system in the lung that has recently gained the most attention for its ability to produce ROS is the NADPH oxidase family of enzymes, also termed the NOX family of enzymes [268]. The primary function of these enzymes was originally viewed as host defense in phagocytic cells against invading microbes, however, NADPH oxidases have now been found in virtually all tissues, and ROS generated by the NADPH oxidases have been shown to have numerous diverse roles in cellular function $[268,269]$. Seven isoforms of the NADPH oxidases have been described in mammals, and the isoform NOX4 is the major NADPH oxidase up regulated by TGF- $\beta 1[29,270]$.

The detrimental effect of ROS is expected to be uniquely most profound in the lung due to its constant 
exposure to the high oxygen tension of the ambient atmosphere. Consequently, the lung has evolved significant defense mechanisms against cellular damage from reactive oxygen species, which most notably include the family of superoxide dismutases (SOD), the peroxidase catalase, and reduced glutathione [263]. Superoxide dismutase has three isoforms and catalyzes the breakdown of superoxide anion to hydrogen peroxide, and catalase accelerates the breakdown of hydrogen peroxide to water. Reduced glutathione (GSH) is a tripeptide containing the amino acid cysteine, and with its sulfhydryl group, acts as one of the major antioxidants present in the lung [271].

\section{Observations in humans}

Most of the observational data suggest that an oxidant/ antioxidant imbalance exists in cells and lung tissue of patients with pulmonary fibrosis. Alveolar inflammatory cells (macrophages, lymphocytes, neutrophils, and eosinophils) and fibroblasts from patients with IPF spontaneously generated higher amounts of ROS than normal controls $[147,148]$. The amount of myeloperoxidase in the alveolar epithelial lining fluid from patients with IPF was also significantly higher than controls, and within the IPF group, those patients with higher levels of myeloperoxidase had a more rapidly deteriorating clinical course than those with lower levels [147]. Whereas alveolar epithelial lining fluid of normal controls contained high levels of GSH [272], patients with IPF had substantially decreased levels of GSH in epithelial lining fluid, BAL fluid, and BAL cells, and had a decreased ratio of reduced to oxidized glutathione (GSH/GSSG) [273-276]. In patients with IPF, immunoreactivity of gamma-glutamylcysteine synthetase, the rate limiting enzyme in reduced glutathione synthesis, was high in areas of regenerating bronchiolar epithelium, but low in fibrotic areas and fibroblastic foci [277]. Extracellular superoxide dismutase (EC-SOD), the major enzyme responsible for inactivating superoxide anion in the extracellular matrix, was absent by immunohistochemistry in fibrotic areas and fibroblastic foci of patients with IPF [278]. Histopathologic sections of lung tissue from patients with IPF showed high expression of the NADPH oxidase isoform NOX4 in fibroblastic foci and in hyperplastic type II cells $[270,279,280]$. The constellation of these findings together suggests a significant oxidant/antioxidant imbalance in the lungs of patients with IPF.

\section{Studies in animal models}

The role of antioxidant defenses or effects of antioxidant therapy have been examined animal models of lung injury and fibrosis. The oxidant/antioxidant balance in the lung may be shifted through administration of the antioxidant $n$-acetylcysteine (NAC), a synthetic precursor of reduced glutathione. Intraperitoneal, oral, or aerosolized NAC lead to reduced inflammation (BAL inflammatory cells and acute inflammatory cytokines) and reduced collagen deposition (hydroxyproline and histology) in the bleomycin model [281-283]. Intraperitoneal administration of the antioxidant MnTBAP, a metalloporphyrin, attenuated lung fibrosis in the bleomycin model as assessed by hydroxyproline content, airway dysfunction, and histopathology [284]. Mice who were germline-deficient for extracellular superoxide dismutase (EC-SOD) and received bleomycin demonstrated a significant increase in inflammation and fibrosis (hydroxyproline and histopathology) compared to wild type controls [285], whereas mice that were transgenic for EC-SOD had less acute lung injury and less fibrosis than wild-type controls [286]. Mice that were genetically deficient of Nrf2, a transcription factor which contributes to GSH homeostasis, had increased inflammation, increased epithelial cell death, and increased indices of lung fibrosis (hydroxyproline content, collagen accumulation, histopathologic score) compared with wild-type controls in response to bleomycin challenge [287].

Additional animal models have examined the role of the NADPH oxidase isoform NOX4. In wild-type mice, administration of bleomycin increased protein expression of NOX4 in a time dependent manner, and instillation of small interfering RNA (siRNA) against NOX4 or pharmacologic inhibition of NOX4 reduced histopathologic evidence of fibrosis, lung homogenate hydroxyproline content, and $\alpha$-SMA production compared with controls [270]. In NOX4-deficient mice, administration of bleomycin resulted in decreased amounts of Smad 2 phosphorylation, $\alpha$-SMA, procollagen mRNA, total collagen content, and histologic fibrosis compared to controls [280]. Although fibrosis was reduced as a result of NOX4 deficiency, the robust pulmonary inflammation in response to bleomycin was not altered, suggesting that inflammation by itself is not sufficient to drive bleomycin-induced fibrosis. Notably, this decreased fibrosis was associated with less alveolar epithelial cell death compared to controls [280]. These results in combination suggest that oxidative stress may be contributing to both alveolar epithelial cell death and lung fibroblast proliferation in pulmonary fibrosis.

\section{Mechanistic in vitro studies}

Many in vitro studies have examined a variety of oxidant and antioxidant mechanisms in lung cells that involve ROS, glutathione, and cysteine. Alveolar inflammatory cells and alveolar epithelial lining fluid from IPF patients are cytotoxic to primary pulmonary epithelial cells; this cytotoxic effect was reduced by the antioxidant enzyme catalase, and did not occur from exposure to cells and 
epithelial fluid from normal controls [147]. Lung fibroblasts exposed to GSH had substantially suppressed cellular proliferation, whereas oxidized glutathione disulfide (GSSG) had no suppressive effect on proliferation [288]. Exposure of lung fibroblasts to the oxidized thiol/disulfide couple cysteine/cystine (Cys/CySS) resulted in enhanced fibroblast proliferation, expression of fibronectin, expression of TGF- $\beta 1$, and expression of Smad3 [289]; these effects did not occur with exposure to reduced Cys/CySS.

Much of the recent mechanistic work regarding oxidative mechanisms in pulmonary fibrosis has centered around the two-way interplay between TGF- $\beta 1$ and ROS mediated processes. ROS have been shown to activate latent TGF- $\beta 1$ [290], and TGF- $\beta 1$ increases production of ROS in human lung fibroblasts [291]. Exposure of epithelial cells and fibroblasts to TGF- $\beta 1$ decreased levels of GSH, decreased levels of the antioxidant enzymes glutathione reductase and catalase, and increased cell cytoxicity mediated by hydrogen peroxide [292-294]. Inhibiting the synthesis of intracellular GSH content in vitro increased TGF- $\beta 1$ mediated collagen production [293]. TGF- $\beta 1$ markedly decreased expression of gamma-glutamylcysteine synthetase [277,292], whereas the acute inflammatory cytokine TNF-alpha caused a mild induction of this enzyme [277]. Lung fibroblasts from patients with IPF that were exposed to TGF- $\beta 1$ generated $\mathrm{H}_{2} \mathrm{O}_{2}$; these fibroblasts were cytotoxic to pulmonary epithelial cells in co-cultures, and this cytotoxic effect was inhibited by the addition of catalase, or by blockade of $\mathrm{H}_{2} \mathrm{O}_{2}$ generation [295]. TGF- $\beta 1$ has been shown to promote epithelialmesenchymal transition (EMT), one of the possible sources of increased resident mesenchymal cells in pulmonary fibrosis [12] . The addition of glutathione, NAC, or ROS inhibitors prevented TGF- $\beta 1$-augmented EMT in alveolar epithelial cells [294], suggesting that oxidative stress mediated by TGF- $\beta 1$ stimulation plays a role in epithelial-mesenchymal transdifferentiation. Additionally, the administration of NAC along with TGF- $\beta 1$ blocked TGF- $\beta 1$-augmented collagen gel contraction, expression of $\alpha$-SMA, and release of fibronectin, vascular endothelial growth factor (VEGF), and collagen $[293,296]$. The mechanisms by which NAC may affect TGF- $\beta 1$ signaling appear diverse, as NAC decreased TGF- $\beta 1$-induced reporter gene activity, decreased phosphorylation of Smad 2/3, reduced active TGF- $\beta 1$ dimer to an inactive TGF- $\beta 1$ monomer, and interfered with TGF- $\beta 1$ receptor signaling [297,298]. These findings suggest that NAC may directly interfere with TGF- $\beta 1$ signaling and function, in addition to its well-established ability to function as a precursor to glutathione synthesis and as a non-specific scavenger of ROS.
In addition to the well-established observations that TGF- $\beta 1$ alters cellular oxidant/antioxidant balance, TGF- $\beta 1$ also specifically induces the expression of the NADPH oxidase isoform NOX4 in numerous mesenchymal cell types. These have included pulmonary artery smooth muscle cells [299,300], cardiac fibroblasts [29], kidney fibroblasts [301], human fetal lung mesenchymal cells [270], and mesenchymal cells from patients with IPF [270]. Furthermore, there has been accumulating evidence that TGF- $\beta 1$-induced expression of NOX4 is closely tied to myofibroblastic differentiation, and that myofibroblast differentiation is dependent on the generation of ROS by NOX4 $[29,270]$.

Exposure of fibroblasts to TGF- $\beta 1$ increased expression of NOX4, superoxide anion, $\alpha$-SMA, and ECMrelated proteins (connective tissue growth factor, fibronectin and collagen) [29]. Attenuation of NOX4 expression by siRNA significantly reduced production of superoxide anion, phosphorylation of Smad 2/3, expression of $\alpha$-SMA, and production of the ECM-related proteins. A similar effect was achieved by inhibiting ROS production with ROS species inhibitors. These findings suggested that TGF- $\beta 1$ stimulation of NOX4 and generation of ROS were essential for Smad 2/3 phosphorylation and for the full manifestation of the myofibroblast phenotype.

Similarly, in human lung mesenchymal cells, TGF- $\beta 1$ induced NOX4 expression, induced extracellular release of hydrogen peroxide $\left(\mathrm{H}_{2} \mathrm{O}_{2}\right)$, upregulated production of $\alpha$-SMA, and caused collagen gel contraction [270]. Pharmacological inhibition of TGF- $\beta 1$ receptor signaling or attenuation of Smad-3 expression by specific siRNA inhibited the induction of NOX4 and the release of $\mathrm{H}_{2} \mathrm{O}_{2}$. The TGF- $\beta 1$-stimulated upregulation of $\alpha$-SMA and collagen gel contraction was inhibited by catalase and by siRNA-mediated inhibition of NOX4. These findings indicated that $\mathrm{H}_{2} \mathrm{O}_{2}$ production from the upregulation of NOX4 was required for TGF- $\beta 1$ to induce differentiation to a myofibroblast phenotype.

\section{Antioxidant therapy in patients with IPF}

Administration of $n$-acetylcysteine (NAC) to patients with IPF increased intracellular GSH content and GSH levels in BAL fluid [274,276,292], and the spontaneous oxidative activity of BAL cells decreased following NAC treatment [274]. One multicenter study has been performed looking at antioxidant therapy in patients with IPF [302]. In this study, patients were randomly assigned to receive either prednisone and azathioprine, or the combination of prednisone, azathioprine and NAC. Patients who received NAC had a better preservation of the vital capacity and the diffusing capacity for carbon monoxide at one year, although there was no demonstrated improvement in survival. Despite the extensive 
amount of data regarding alterations in the oxidant/antioxidant balance in lungs with pulmonary fibrosis, administration of antioxidant therapy to patients has not yet been shown to provide clear-cut clinical benefit [7].

\section{Procoagulant milieu in the lung}

Essential in the process of wound healing in response to tissue injury are procoagulant signaling mechanisms. Activation of the coagulation cascade by tissue injury contributes to both cessation of bleeding as well as tissue repair. Over the past 15 years, there has been an accumulation of evidence in humans and animal models that imbalances in procoagulant or antifibrinolytic activity are present in the lungs of patients with pulmonary fibrosis. Most of the descriptions of these imbalances have centered on abnormalities of tissue factor, factor Xa, thrombin, or proteinase-activated receptors.

\section{Overview of coagulation}

Coagulation is most often initiated at sites of tissue injury, at which time tissue factor (TF), a transmembrane glycoprotein widely expressed on vascular interstitial cells, becomes exposed to plasma serine proteinases $[303,304]$. As TF binds to activated factor VIIa in plasma, the extrinsic coagulation pathway begins and continues with the activation of factor $\mathrm{X}$ to factor $\mathrm{Xa}$, conversion of prothrombin to thrombin, and conversion of fibrinogen to fibrin, the main component of a mature thrombus. Additional activation of the intrinsic coagulation pathway by thrombin results in the desired effect of sustained hemostasis at sites of tissue injury [305]. The coagulation process is normally opposed by fibrinolysis, the process of cleaving fibrin into degradation products, which is initiated when plasminogen is converted to plasmin by plasminogen activators [305]. The activity of plasminogen activators is balanced by the presence of plasminogen activator inhibitors, and additional naturally occurring anticoagulants include tissue factor pathway inhibitor, which inactivates the TF/VIIa complex, and activated protein $\mathrm{C}$, which inactivates factor $\mathrm{V}$ and PAI-1 [305,306].

In addition to promoting hemostasis, thrombin and several of the activated coagulation proteinases bind to members of a family of proteinase-activated receptors (PARs). PARs are transmembrane G-protein coupled receptors that have a unique mechanism of activation in which a portion of the receptor (the tethered ligand) is cleaved by proteolysis and then functions as the ligand for the receptor [305]. Binding of ligand to the major thrombin receptor PAR-1 has been shown to cause multiple downstream effects related broadly to wound healing and repair, and specifically to inflammation, epithelial and mesenchymal cell function, and TGF- $\beta$.

\section{Observations in humans Epidemiologic clues}

Epidemiologic observations in humans have suggested a relationship between disorders of the coagulation system and the development of pulmonary fibrosis. In a large cohort of patients in Denmark, patients who were homozygous for a mutation in factor $\mathrm{V}$ (factor V Leiden) had abnormalities of several respiratory indices when compared to non-carriers, which included an increase in severe dyspnea, lower forced expiratory volume in one second $\left(\mathrm{FEV}_{1}\right)$ and forced vital capacity $(\mathrm{FVC})$, and increased rate of annual decline in the $\mathrm{FEV}_{1}$ and $\mathrm{FVC}$ [307]. In another large cohort of patients from Denmark, the relationship between a history of deep venous thrombosis or pulmonary embolism was correlated with the presence of interstitial lung disease or idiopathic interstitial pneumonia [308]. The incidence rates of idiopathic interstitial pneumonia and interstitial lung disease were higher in patients with a history of venous thromboembolism or pulmonary embolism than control patients.

\section{Tissue factor (TF)}

Elevated levels of TF in BAL fluid have been found in patients with IPF compared with normal controls, and in patients with an acute exacerbation of IPF, BAL levels of TF were markedly elevated [309]. Immunohistochemical analyses revealed large amounts of TF in cuboidal epithelial cells in patients with IPF [309], and in type II pneumocytes of patients with IPF, systemic sclerosis, and cryptogenic organizing pneumonia [310]. Increased TF mRNA and protein were seen in fibroblasts from IPF patients compared with normal lung fibroblasts, and expression of TF assessed by qRT-PCR was up-regulated in fibroblastic foci of these IPF patients [311]. Procoagulant activity was increased in patients with IPF and other forms of diffuse parenchymal lung disease, and this increase in procoagulant activity was TF-dependent [312]. Interestingly, this TF-dependent increase in procoagulant activity correlated with a reduction in lung compliance, which is well-known to occur in patients with IPF.

\section{Factor VII and Factor $X$}

Increases in factor VII antigen in BAL fluid and mRNA in alveolar type II epithelial cells were detected in the lungs of patients with IPF compared with normal lung tissue [311]. Similarly, increased expression of factor X mRNA was seen in alveolar septa in the lungs of patients with IPF, whereas there was no significant expression of factor $\mathrm{X}$ in normal healthy lung tissue [152].

\section{Anti-fibrinolytic activity}

Contributing to the balance between procoagulant and anticoagulant mechanisms in the lung are the fibrinolytic 
plasminogen activators (urokinase-type and tissue-type) and the anti-fibrinolytic plasminogen activator inhibitors (plasminogen activator inhibitor 1 [PAI-1] and plasminogen activator inhibitor 2 [PAI-2]). BAL levels of PAI-1 and PAI-2 were elevated in patients with IPF $v s$ control patients, accompanied by no difference in urokinase-type plasminogen activator levels, suggesting an imbalance shifted towards anti-fibrinolytic (or procoagulant) activity in the lungs of patients with IPF [309].

\section{PAR-1 and PAR-2}

The major thrombin receptor PAR-1 was highly expressed in macrophages and fibroblasts within fibroproliferative foci in patients with IPF, whereas there was only weak staining by immunohistochemistry for PAR-1 in resident alveolar macrophages from normal lung tissue [152,153]. Similarly, in patients with systemic sclerosis, PAR-1 expression by immunohistochemistry was elevated in areas of inflammation and fibroproliferation, but showed only minimal expression in normal control patients [313]. Recently, PAR-1 expression was shown to be up-regulated on activated epithelium within the fibrotic areas of IPF patients, and additionally, was co-expressed in these epithelial cells with chemokine CCL2, also known as monocyte chemotactic protein-1 (MCP-1) [314].

In addition to PAR-1, increased expression of mRNA and protein of PAR-2, which is activated by tissue factor, factor VIIa, and factor Xa, but not by thrombin, was found in lung homogenates and fibroblasts of patients with IPF compared with controls [305,311]. Increased expression of PAR-2 by immunohistochemistry was also seen in type II alveolar epithelial cells and in fibroblastic foci, and tissue factor (TF) co-localized with PAR-2 in these fibroblastic foci [311].

\section{Studies in animal models}

Consistent with an overall procoagulant milieu, administration of bleomycin has been shown to increase expression of procoagulant activity and thrombin in BAL [315], increase PAR-1 expression in lung tissue, alveolar epithelium, and bronchial epithelium [314,316], increase factor $\mathrm{X}$ gene expression and factor $\mathrm{X}$ mRNA levels [152], and decrease levels of activated protein C [306]. Administration of molecules which favor an anticoagulant milieu has also been performed in the bleomycin model. Aerosolization of heparin or urokinase-type plasminogen activator following bleomycin challenge resulted in reduced soluble collagen and hydroxyproline accumulation, reduced histologic and CT features of fibrosis, and improved lung compliance [317]. Intratracheal administration of activated protein $\mathrm{C}$ along with bleomycin resulted in less fibrosis, less hydroxyproline content, and a higher ratio of plasminogen activator to thrombin activity than controls [306]. Administration of a direct thrombin inhibitor along with bleomycin resulted in reduced lung collagen accumulation and connective tissue growth factor (CTGF) mRNA compared with controls [316]. Administration of a direct factor Xa inhibitor along with bleomycin resulted in reduced total lung collagen accumulation compared with bleomycin treatment alone [152]. Adenovirus-mediated gene delivery of tissue factor pathway inhibitor along with bleomycin challenge decreased procoagulant and thrombin activity in BAL, reduced the expression of connective tissue growth factor (CTGF) and TGF- $\beta 1$ mRNA in $\mathrm{BAL}$, reduced hydroxyproline accumulation in the lungs, and reduced histologic evidence of fibrosis [315].

The effects of gene deletion or insertion using transgene technology have also been studied in the bleomycin model. Administration of bleomycin to mice deficient in PAR-1 resulted in reductions in inflammatory cell recruitment, BAL protein, total lung collagen accumulation, and pulmonary levels of MCP-1 and TGF- $\beta 1$ compared with controls [153]. Administration of bleomycin to mice transgenic for overexpression of PAI-1 resulted in increased lung hydroxyproline content, whereas lung hydroxyproline content and lung histology in PAI-1 deficient mice were not significantly different than that of mice treated with saline alone [318].

\section{Mechanistic in vitro studies}

Activation of fibroblasts by one or more of the coagulation proteinases via proteinase-activated receptors (PARs) has been studied extensively in vitro over the last fifteen years in relation to the ability to promote fibroblast proliferation and extracellular matrix production. Thrombin is a known mitogen for human lung fibroblasts and inhibits fibroblast apoptosis [311,313,319323]. Thrombin stimulated mitogen-activated protein (MAP) kinase activation and DNA synthesis in normal mouse fibroblasts, and these responses were absent in fibroblasts from thrombin receptor knockout mice [319]. In addition to its mitogenic effect, thrombin increased production of procollagen in human lung fibroblasts in a dose-dependent manner [324,325]. This increase in procollagen was mimicked by agonist peptides for PAR-1 and abolished by inhibitors of thrombin's proteolytic activity, suggesting that thrombin was exerting its effects via PAR-1 [324]. Furthermore, thrombin caused collagen gel contraction and stimulated the production of $\alpha$-SMA in normal human lung fibroblasts in a dose- and timedependent manner [320], indicating fibroblast differentiation to a myofibroblast phenotype. Both of these effects were mediated via PAR-1 and subsequent protein kinase $\mathrm{C}$-mediated intracellular signaling, and both occurred independently of TGF- $\beta 1$ [320]. In human fetal and adult lung fibroblasts, thrombin increased production and synthesis of connective tissue disease growth factor 
(CTGF), a potent fibroblast mitogen [37]. This increased production of CTGF occurred via PAR-1 and was independent of TGF- $\beta 1$.

Similar to thrombin, factor $\mathrm{Xa}$ increased fibroblast proliferation in human and mouse lung fibroblasts $[311,321,325]$, and stimulated procollagen-alpha 1 (I) promoter activity and procollagen production in human and mouse lung fibroblasts [325]. These effects on collagen were mediated via PAR-1, since factor Xa had no effect on procollagen production in PAR-1 deficient mouse lung fibroblasts [325]. Similar to thrombin, factor $\mathrm{Xa}$ increased production and synthesis of CTGF mRNA in human lung fibroblasts [37].

Although the above studies indicate that the profibrotic effects of thrombin and factor $\mathrm{Xa}$ are mediated predominantly via PAR-1, a similar role for PAR-2 in pulmonary fibrosis has recently been suggested. Exposure of human lung fibroblasts to TGF- $\beta 1$ increased expression of PAR-2 mRNA and protein [311]. One of the known ligands for PAR-2 is factor VIIa, and factor VIIa exhibited mitogenic effects on human lung fibroblasts [311,321]. This mitogenic effect was mediated via PAR-2 and TF, since it was inhibited by siRNAs against PAR-2 or TF, and was greatly enhanced by the simultaneous overexpression of both receptors [311].

The proliferative and profibrotic effects of the coagulation proteinases on fibroblasts may not only be direct, but may also occur through indirect mechanisms. One described indirect mechanism is activation of PAR-1 on epithelial cells leading to integrin-mediated activation of latent TGF- $\beta 1$ [152,326]. Another indirect mechanism relates to the described role of epithelial apoptosis in pulmonary fibrosis. Activation of PAR-1 with thrombin or a PAR-1 agonist led to apoptosis of pulmonary epithelial cells, which was reduced by treatment with a PAR-1 inhibitor and in cells with reduced PAR-1 expression via gene silencing [327]. Based on the multiple effects of PAR-1 activation, it is interesting to note that thrombin induced apoptosis in epithelial cells, but inhibited apoptosis in lung fibroblasts. These findings are consistent with one of the major proposed mechanisms for IPF in which pulmonary fibrosis is driven by a combination of apoptosis of epithelial cells and numerical expansion of fibroblasts and myofibroblasts.

\section{Anticoagulation therapy in patients with IPF}

Two trials have been published examining the effects of anticoagulation therapy in patients with IPF. In a study of 20 patients with IPF, the safety and tolerability of inhaled heparin were examined, and demonstrated safety of inhaled heparin and an overall stability in pulmonary function parameters and quality of life scores [328]. In a randomized study of 56 patients, those who received anticoagulation therapy along with prednisolone had an improved overall survival compared with patients treated with prednisolone alone [329], but this study did have limitations which reduced the ability to make generalized conclusions [7]. Despite the extensive amount of data indicating the profibrotic activity of the coagulation proteinases and the procoagulant milieu in the fibrotic lung, administration of anticoagulation therapy to patients has not been shown to provide clear-cut clinical benefit, and is not currently recommended [7].

\section{Conclusions}

Pulmonary fibrosis is a chronic condition of the lungs with characteristic clinical, radiographic, physiologic, and pathologic findings. At the present time, no proven effective therapies exist for pulmonary fibrosis. In some patients, lung injury and subsequent fibrosis occur in which the deposition of excess ECM seems to cease, the impairment in lung function is mild, and the lack of effective therapies does not adversely impact patients. In other patients such as those with IPF, the deposition of excess ECM appears to be progressive, impairment in lung function is severe, and the lack of effective therapies in these patients results in the morbidity and mortality from this disease.

One limitation to advancing our knowledge in this field is that none of the currently accepted animal models of pulmonary fibrosis (bleomycin, radiation, silica, transgenic, viral vectors) accurately mimic human IPF [330,331]. Despite this limitation, an extensive amount of mechanistic work has been performed using these models, with a resultant immense amount of insight gained into epithelial and mesenchymal cell biology of pulmonary fibrosis. In this review, we have attempted to provide an overview of three broad areas which have been explored, and which may be responsible for the observed epithelial, mesenchymal, and ECM abnormalities: inflammation and immune mechanisms, oxidative stress and oxidative signaling, and procoagulant mechanisms. In each of these processes, there is a preponderance of mechanistic, animal model, and human data indicating that disturbances in these mechanisms exist, but at present, pharmacologic targeting of these disturbances in patients has not resulted in improved outcomes. Continued efforts aimed at determining the precise relationship between these disturbances and the development of fibrosis will hopefully lead to effective therapies for patients in the future.

\section{Abbreviations}

a-SMA: Alpha-smooth muscle actin; ECM: Extracellular matrix; ECSOD: Extracellular superoxide dismutase; EMT: Epithelial mesenchymal transition; GSH: Reduced glutathione; $\mathrm{H}_{2} \mathrm{O}_{2}$ : Hydrogen peroxide; IPF: Idiopathic pulmonary fibrosis; NAC: $n$-acetylcysteine; NOX: NADPH oxidase; $\mathrm{O}_{2}^{-}$: Superoxide anion; ROS: Reactive oxygen species; siRNA: Small interfering RNA; TGF- $\beta$ : Transforming growth factor-beta; UIP: Usual interstitial pneumonia. 


\section{Competing interests}

The authors declare they have no competing interests.

\section{Author details}

'Department of Medicine, University of Maryland School of Medicine, Baltimore, MD, USA. ${ }^{2}$ VA Medical Center, Baltimore, MD, USA. ${ }^{3}$ Division of Pulmonary and Critical Care Medicine, University of Maryland School of Medicine, 110 S. Paca St., Baltimore, MD 21201, USA.

\section{Authors' contributions}

This manuscript has been seen and approved by all co-authors, and all authors contributed sufficiently to warrant their inclusion on the author list and to take responsibility for the content of this report.

Received: 2 April 2012 Accepted: 28 June 2012

Published: 23 July 2012

\section{References}

1. Takishima T, Shimura S: Definition and Classification of Pulmonary Fibrosis. In Basic and clinical aspects of pulmonary fibrosis. Edited by Takishima T. Boca Raton, FL: CRC Press; 1994:293-303.

2. Orr CR, Jacobs WF: Pulmonary Fibrosis. Radiology 1926, 7:318-325.

3. Hamman L, Rich AR: Fulminating diffuse interstitial fibrosis of the lungs. Trans Am Clin Climatol Assoc 1935, 51:154-163.

4. Hamman L, Rich A: Acute diffuse interstitial fibrosis of the lungs. Bull Johns Hopkins Hosp 1944, 74:177-212.

5. Scadding JG, Hinson KF: Diffuse fibrosing alveolitis (diffuse interstitial fibrosis of the lungs). Correlation of histology at biopsy with prognosis. Thorax 1967, 22:291-304.

6. Crystal RG, Fulmer JD, Roberts WC, Moss ML, Line BR, Reynolds HY: Idiopathic pulmonary fibrosis. Clinical, histologic, radiographic, physiologic, scintigraphic, cytologic, and biochemical aspects. Ann Intern Med 1976, 85:769-788.

7. Raghu G, Collard HR, Egan JJ, Martinez FJ, Behr J, Brown KK, Colby TV, Cordier JF, Flaherty KR, Lasky JA, Lynch DA, Ryu JH, Swigris JJ, Wells AU, Ancochea J, Bouros D, Carvalho C, Costabel U, Ebina M, Hansell DM, Johkoh T, Kim DS, King TE Jr, Kondoh Y, Myers J, Müller NL, Nicholson AG, Richeldi L, Selman M, Dudden RF, et al: An official ATS/ERS/JRS/ALAT statement: idiopathic pulmonary fibrosis: evidence-based guidelines for diagnosis and management. Am J Respir Crit Care Med 2011, 183:788-824.

8. Hashimoto N, Jin H, Liu T, Chensue SW, Phan SH: Bone marrow-derived progenitor cells in pulmonary fibrosis. J Clin Invest 2004, 113:243-252.

9. Bucala R, Spiegel LA, Chesney J, Hogan M, Cerami A: Circulating fibrocytes define a new leukocyte subpopulation that mediates tissue repair. $\mathrm{Mol}$ Med 1994, 1:71-81.

10. Kuwana M, Okazaki Y, Kodama H, Izumi K, Yasuoka H, Ogawa Y, Kawakami Y, Ikeda Y: Human circulating CD14+ monocytes as a source of progenitors that exhibit mesenchymal cell differentiation. J Leukoc Biol 2003, 74:833845 .

11. Postlethwaite $A E$, Shigemitsu $H$, Kanangat $S$ : Cellular origins of fibroblasts: possible implications for organ fibrosis in systemic sclerosis. Curr Opin Rheumatol 2004, 16:733-738.

12. Willis BC, Liebler JM, Luby-Phelps K, Nicholson AG, Crandall ED, du Bois RM, Borok $Z$ : Induction of epithelial-mesenchymal transition in alveolar epithelial cells by transforming growth factor-beta1: potential role in idiopathic pulmonary fibrosis. Am J Pathol 2005, 166:1321-1332.

13. Coalson JJ: The ultrastructure of human fibrosing alveolitis. Virchows Arch A Pathol Anat Histol 1982, 395:181-199.

14. Kawanami O, Ferrans VJ, Crystal RG: Structure of alveolar epithelial cells in patients with fibrotic lung disorders. Lab Invest 1982, 46:39-53.

15. du Bois RM, Wells AU: Cryptogenic fibrosing alveolitis/idiopathic pulmonary fibrosis. Eur Respir J 2001, 32(Suppl 1):43s-55s.

16. Katzenstein AL, Myers JL: Idiopathic pulmonary fibrosis: clinical relevance of pathologic classification. Am J Respir Crit Care Med 1998, 157:1301-1315.

17. Leslie KO: Pathology of the idiopathic interstitial pneumonias. Exp Lung Res 2005, 31(Suppl 1):23-40.

18. American Thoracic Society; European Respiratory Society: American Thoracic Society/European Respiratory Society International Multidisciplinary Consensus Classification of the Idiopathic Interstitial Pneumonias. This joint statement of the American Thoracic Society (ATS), and the European Respiratory Society (ERS) was adopted by the
ATS board of directors, June 2001 and by the ERS Executive Committee, June 2001. Am J Respir Crit Care Med

2002, 165:277-304.

19. Selman M, King TE, Pardo A: Idiopathic pulmonary fibrosis: prevailing and evolving hypotheses about its pathogenesis and implications for therapy. Ann Intern Med 2001, 134:136-151.

20. Horowitz JC, Thannickal VJ: Epithelial-mesenchymal interactions in pulmonary fibrosis. Semin Respir Crit Care Med 2006, 27:600-612.

21. Richeldi L, Davies HR, Ferrara G, Franco F: Corticosteroids for idiopathic pulmonary fibrosis. Cochrane Database Syst Rev 2003, 3:CD002880.

22. Davies HR, Richeldi L, Walters EH: Immunomodulatory agents for idiopathic pulmonary fibrosis. Cochrane Database Syst Rev 2003, 3: CD003134.

23. Barnes PJ, Adcock IM: Glucocorticoid resistance in inflammatory diseases. Lancet 2009, 373:1905-1917.

24. Homer RJ, Elias JA, Lee CG, Herzog E: Modern concepts on the role of inflammation in pulmonary fibrosis. Arch Pathol Lab Med 2011, 135:780-788.

25. Wynn TA: Integrating mechanisms of pulmonary fibrosis. J Exp Med 2011, 208:1339-1350.

26. Crystal RG, Bitterman PB, Mossman B, Schwarz MI, Sheppard D, Almasy L, Chapman HA, Friedman SL, King TE Jr, Leinwand LA, Liotta L, Martin GR, Schwartz DA, Schultz GS, Wagner CR, Musson RA: Future research directions in idiopathic pulmonary fibrosis: summary of a National Heart, Lung, and Blood Institute working group. Am J Respir Crit Care Med 2002, 166:236-246.

27. Tanaka T, Yoshimi M, Maeyama T, Hagimoto N, Kuwano K, Hara N: Resistance to Fas-mediated apoptosis in human lung fibroblast. Eur Respir J 2002, 20:359-368.

28. Hagimoto N, Kuwano K, Inoshima I, Yoshimi M, Nakamura N, Fujita M, Maeyama T, Hara N: TGF-beta 1 as an enhancer of Fas-mediated apoptosis of lung epithelial cells. J Immunol 2002, 168:6470-6478.

29. Cucoranu I, Clempus R, Dikalova A, Phelan PJ, Ariyan S, Dikalov S, Sorescu D: $\mathrm{NAD}(\mathrm{P}) \mathrm{H}$ oxidase 4 mediates transforming growth factor-beta1-induced differentiation of cardiac fibroblasts into myofibroblasts. Circ Res 2005 97:900-907.

30. Gharaee-Kermani M, Hu B, Phan SH, Gyetko MR: Recent advances in molecular targets and treatment of idiopathic pulmonary fibrosis: focus on TGFbeta signaling and the myofibroblast. Curr Med Chem 2009, 16:1400-1417.

31. Cutroneo KR, White SL, Phan SH, Ehrlich HP: Therapies for bleomycin induced lung fibrosis through regulation of TGF-beta1 induced collagen gene expression. J Cell Physiol 2007, 211:585-589.

32. Border WA, Noble NA: Transforming growth factor beta in tissue fibrosis N Engl J Med 1994, 331:1286-1292.

33. Sime PJ, Xing Z, Graham FL, Csaky KG, Gauldie J: Adenovector-mediated gene transfer of active transforming growth factor-beta1 induces prolonged severe fibrosis in rat lung. J Clin Invest 1997, 100:768-776.

34. Sheppard D: Transforming growth factor beta: a central modulator of pulmonary and airway inflammation and fibrosis. Proc Am Thorac Soc 2006, 3:413-417.

35. Gauldie J, Bonniaud P, Sime P, Ask K, Kolb M: TGF-beta, Smad3 and the process of progressive fibrosis. Biochem Soc Trans 2007, 35:661-664.

36. Biernacka A, Dobaczewski M, Frangogiannis NG: TGF-beta signaling in fibrosis. Growth Factors 2011, 29:196-202.

37. Chambers RC, Leoni P, Blanc-Brude OP, Wembridge DE, Laurent GJ: Thrombin is a potent inducer of connective tissue growth factor production via proteolytic activation of protease-activated receptor-1. J Biol Chem 2000, 275:35584-35591.

38. Atamas SP: Complex cytokine regulation of tissue fibrosis. Life Sci 2002 72:631-643

39. Atamas SP, White B: Cytokine regulation of pulmonary fibrosis in scleroderma. Cytokine Growth Factor Rev 2003, 14:537-550.

40. Ihn H: Pathogenesis of fibrosis: role of TGF-beta and CTGF. Curr Opin Rheumatol 2002, 14:681-685.

41. Lasky JA, Ortiz LA, Tonthat B, Hoyle GW, Corti M, Athas G, Lungarella G, Brody A, Friedman M: Connective tissue growth factor mRNA expression is upregulated in bleomycin-induced lung fibrosis. Am J Physiol 1998, 275: L365-L371.

42. Duncan MR, Frazier KS, Abramson S, Williams S, Klapper H, Huang X, Grotendorst GR: Connective tissue growth factor mediates transforming 
growth factor beta-induced collagen synthesis: down-regulation by CAMP. FASEB J 1999, 13:1774-1786.

43. Bonniaud P, Margetts PJ, Kolb M, Haberberger T, Kelly M, Robertson J, Gauldie $\mathrm{J}$ : Adenoviral gene transfer of connective tissue growth factor in the lung induces transient fibrosis. Am J Respir Crit Care Med 2003, 168:770-778.

44. Kottmann RM, Hogan CM, Phipps RP, Sime PJ: Determinants of initiation and progression of idiopathic pulmonary fibrosis. Respirology 2009, 14:917-933.

45. Lo Re S, Lecocq M, Uwambayinema F, Yakoub Y, Delos M, Demoulin JB, Lucas S, Sparwasser T, Renauld JC, Lison D, Huaux F: Platelet-derived growth factor-producing CD4+ Foxp3+ regulatory T lymphocytes promote lung fibrosis. Am J Respir Crit Care Med 2011, 184:1270-1281.

46. Trojanowska M: Role of PDGF in fibrotic diseases and systemic sclerosis. Rheumatology (Oxford) 2008, 47(Suppl 5):v2-v4.

47. Bonner JC: Regulation of PDGF and its receptors in fibrotic diseases. Cytokine Growth Factor Rev 2004, 15:255-273.

48. Abdollahi A, Li M, Ping G, Plathow C, Domhan S, Kiessling F, Lee LB, McMahon G, Gröne HJ, Lipson KE, Huber PE: Inhibition of platelet-derived growth factor signaling attenuates pulmonary fibrosis. J Exp Med 2005, 201:925-935.

49. Daniels CE, Lasky JA, Limper AH, Mieras K, Gabor E, Schroeder DR, ImatinibIPF Study Investigators: Imatinib treatment for idiopathic pulmonary fibrosis: Randomized placebo-controlled trial results. Am J Respir Crit Care Med 2010, 181:604-610.

50. Aono Y, Nishioka Y, Inayama M, Ugai M, Kishi J, Uehara H, Izumi K, Sone S. Imatinib as a novel antifibrotic agent in bleomycin-induced pulmonary fibrosis in mice. Am J Respir Crit Care Med 2005, 171:1279-1285.

51. Mio T, Nagai S, Kitaichi M, Kawatani A, Izumi T: Proliferative characteristics of fibroblast lines derived from open lung biopsy specimens of patients with IPF (UIP). Chest 1992, 102:832-837.

52. Hetzel M, Bachem M, Anders D, Trischler G, Faehling M: Different effects of growth factors on proliferation and matrix production of normal and fibrotic human lung fibroblasts. Lung 2005, 183:225-237.

53. Bonner JC, Osornio-Vargas AR, Badgett A, Brody AR: Differential proliferation of rat lung fibroblasts induced by the platelet-derived growth factor- $A \mathrm{~A},-\mathrm{AB}$, and $-\mathrm{BB}$ isoforms secreted by rat alveolar macrophages. Am J Respir Cell Mol Biol 1991, 5:539-547.

54. Osornio-Vargas AR, Goodell AL, Hernández-Rodríguez NA, Brody AR, Coin $P G$, Badgett $A$, Bonner JC: Platelet-derived growth factor (PDGF)-AA, $-A B$, and $-B B$ induce differential chemotaxis of early-passage rat lung fibroblasts in vitro. Am J Respir Cell Mol Biol 1995, 12:33-40.

55. Goldstein RH, Poliks CF, Pilch PF, Smith BD, Fine A: Stimulation of collagen formation by insulin and insulin-like growth factor I in cultures of human lung fibroblasts. Endocrinology 1989, 124:964-970.

56. Gillery P, Leperre A, Maquart FX, Borel JP: Insulin-like growth factor-I (IGF-I) stimulates protein synthesis and collagen gene expression in monolayer and lattice cultures of fibroblasts. J Cell Physiol 1992, 152:389-396.

57. Hsu E, Feghali-Bostwick CA: Insulin-like growth factor-II is increased in systemic sclerosis-associated pulmonary fibrosis and contributes to the fibrotic process via Jun N-terminal kinase- and phosphatidylinositol-3 kinase-dependent pathways. Am J Pathol 2008, 172:1580-1590

58. Frankel SK, Moats-Staats BM, Cool CD, Wynes MW, Stiles AD, Riches DW: Human insulin-like growth factor-IA expression in transgenic mice promotes adenomatous hyperplasia but not pulmonary fibrosis. Am J Physiol 2005, 288:L805-L812.

59. Maeda A, Hiyama K, Yamakido H, Ishioka S, Yamakido M: Increased expression of platelet-derived growth factor $A$ and insulin-like growth factor-I in BAL cells during the development of bleomycin-induced pulmonary fibrosis in mice. Chest 1996, 109:780-786.

60. Gordon S, Martinez FO: Alternative activation of macrophages: mechanism and functions. Immunity 2010, 32:593-604.

61. Atamas SP, Luzina IG, Dai H, Wilt SG, White B: Synergy between CD40 ligation and IL-4 on fibroblast proliferation involves IL-4 receptor signaling. J Immunol 2002, 168:1139-1145.

62. Jakubzick C, Kunkel SL, Puri RK, Hogaboam CM: Therapeutic targeting of IL-4- and IL-13-responsive cells in pulmonary fibrosis. Immunol Res 2004, 30:339-349.

63. Fuschiotti P: Role of IL-13 in systemic sclerosis. Cytokine 2011, 56:544-549

64. Joshi BH, Hogaboam C, Dover P, Husain SR, Puri RK: Role of interleukin-13 in cancer, pulmonary fibrosis, and other $\mathrm{T}(\mathrm{H}) 2$-type diseases. Vitam Horm 2006, 74:479-504.
65. Gharaee-Kermani M, Nozaki Y, Hatano K, Phan SH: Lung interleukin-4 gene expression in a murine model of bleomycin-induced pulmonary fibrosis. Cytokine 2001, 15:138-147.

66. Monroe JG, Haldar S, Prystowsky MB, Lammie P: Lymphokine regulation of inflammatory processes: interleukin-4 stimulates fibroblast proliferation. Clin Immunol Immunopathol 1988, 49:292-298.

67. Postlethwaite $A E$, Holness MA, Katai H, Raghow R: Human fibroblasts synthesize elevated levels of extracellular matrix proteins in response to interleukin 4. J Clin Invest 1992, 90:1479-1485.

68. Wilson MS, Wynn TA: Pulmonary fibrosis: pathogenesis, etiology and regulation. Mucosal Immunol 2009, 2:103-121.

69. Wynes MW, Edelman BL, Kostyk AG, Edwards MG, Coldren C, Groshong SD, Cosgrove GP, Redente EF, Bamberg A, Brown KK, Reisdorph N, Keith RC, Frankel SK, Riches DW: Increased cell surface Fas expression is necessary and sufficient to sensitize lung fibroblasts to Fas ligation-induced apoptosis: implications for fibroblast accumulation in idiopathic pulmonary fibrosis. J Immunol 2011, 187:527-537.

70. King TE Jr, Albera C, Bradford WZ, Costabel U, Hormel P, Lancaster L, Noble PW, Sahn SA, Szwarcberg J, Thomeer M, Valeyre D, du Bois RM, INSPIRE Study Group: Effect of interferon gamma-1b on survival in patients with idiopathic pulmonary fibrosis (INSPIRE): a multicentre, randomised, placebo-controlled trial. Lancet 2009, 374:222-228.

71. Raghu G, Brown KK, Bradford WZ, Starko K, Noble PW, Schwartz DA, King TE Jr, Idiopathic Pulmonary Fibrosis Study Group: A placebo-controlled trial of interferon gamma-1b in patients with idiopathic pulmonary fibrosis. N Engl J Med 2004, 350:125-133.

72. Kim JH, Kim HY, Kim S, Chung JH, Park WS, Chung DH: Natural killer T (NKT) cells attenuate bleomycin-induced pulmonary fibrosis by producing interferon-gamma. Am J Pathol 2005, 167:1231-1241.

73. Gurujeyalakshmi G, Giri SN: Molecular mechanisms of antifibrotic effect of interferon gamma in bleomycin-mouse model of lung fibrosis: downregulation of TGF-beta and procollagen I and III gene expression. Exp Lung Res 1995, 21:791-808.

74. Duncan MR, Berman B: Gamma interferon is the lymphokine and beta interferon the monokine responsible for inhibition of fibroblast collagen production and late but not early fibroblast proliferation. J Exp Med 1985, 162:516-527.

75. Yuan W, Yufit T, Li L, Mori Y, Chen SJ, Varga J: Negative modulation of alpha1(I) procollagen gene expression in human skin fibroblasts: transcriptional inhibition by interferon-gamma. J Cell Physiol 1999, 179:97-108.

76. Gillery $P$, Serpier $H$, Polette M, Bellon G, Clavel C, Wegrowski Y, Birembaut $P$, Kalis B, Cariou R, Maquart FX: Gamma-interferon inhibits extracellular matrix synthesis and remodeling in collagen lattice cultures of normal and scleroderma skin fibroblasts. Eur J Cell Biol 1992, 57:244-253.

77. Wynn TA: Fibrotic disease and the $\mathrm{T}(\mathrm{H}) 1 / \mathrm{T}(\mathrm{H}) 2$ paradigm. Nat Rev Immunol 2004, 4:583-594.

78. Hoshino T, Okamoto M, Sakazaki Y, Kato S, Young HA, Aizawa H: Role of proinflammatory cytokines IL-18 and IL-1beta in bleomycin-induced lung injury in humans and mice. Am J Respir Cell Mol Biol 2009, 41:661-670.

79. Kolb M, Margetts PJ, Anthony DC, Pitossi F, Gauldie J: Transient expression of IL-1beta induces acute lung injury and chronic repair leading to pulmonary fibrosis. J Clin Invest 2001, 107:1529-1536.

80. Diaz A, Munoz E, Johnston R, Korn JH, Jimenez SA: Regulation of human lung fibroblast alpha $1(\mathrm{I})$ procollagen gene expression by tumor necrosis factor alpha, interleukin-1 beta, and prostaglandin E2. J Biol Chem 1993, 268:10364-10371.

81. Bhatnagar R, Penfornis H, Mauviel A, Loyau G, Saklatvala J, Pujol JP: Interleukin-1 inhibits the synthesis of collagen by fibroblasts. Biochem Int 1986, 13:709-720.

82. Mauviel A, Heino J, Kähäri VM, Hartmann DJ, Loyau G, Pujol JP, Vuorio E: Comparative effects of interleukin-1 and tumor necrosis factor-alpha on collagen production and corresponding procollagen mRNA levels in human dermal fibroblasts. J Invest Dermatol 1991, 96:243-249.

83. Postlethwaite $A E$, Lachman LB, Kang $A H$ : Induction of fibroblast proliferation by interleukin-1 derived from human monocytic leukemia cells. Arthritis Rheum 1984, 27:995-1001.

84. Ortiz LA, Lasky J, Hamilton RF Jr, Holian A, Hoyle GW, Banks W, Peschon JJ, Brody AR, Lungarella G, Friedman M: Expression of TNF and the necessity of TNF receptors in bleomycin-induced lung injury in mice. Exp Lung Res 1998, 24:721-743. 
85. Sime PJ, Marr RA, Gauldie D, Xing Z, Hewlett BR, Graham FL, Gauldie J: Transfer of tumor necrosis factor-alpha to rat lung induces severe pulmonary inflammation and patchy interstitial fibrogenesis with induction of transforming growth factor-beta1 and myofibroblasts. Am J Pathol 1998, 153:825-832.

86. Chou DH, Lee W, McCulloch CA: TNF-alpha inactivation of collagen receptors: implications for fibroblast function and fibrosis. J Immunol 1996, 156:4354-4362.

87. Postlethwaite AE, Seyer JM: Stimulation of fibroblast chemotaxis by human recombinant tumor necrosis factor alpha (TNF-alpha) and a synthetic TNF-alpha 31-68 peptide. J Exp Med 1990, 172:1749-1756.

88. Raghu G, Brown KK, Costabel U, Cottin V, du Bois RM, Lasky JA, Thomeer M, Utz JP, Khandker RK, McDermott L, Fatenejad S: Treatment of idiopathic pulmonary fibrosis with etanercept: an exploratory, placebo-controlled trial. Am J Respir Crit Care Med 2008, 178:948-955.

89. Wilson MS, Madala SK, Ramalingam TR, Gochuico BR, Rosas IO, Cheever AW, Wynn TA: Bleomycin and IL-1 beta-mediated pulmonary fibrosis is IL-17A dependent. J Exp Med 2010, 207:535-552.

90. Simonian PL, Roark CL, Wehrmann F, Lanham AK, Diaz del Valle F, Born WK, O'Brien RL, Fontenot AP: Th17-polarized immune response in a murine model of hypersensitivity pneumonitis and lung fibrosis. J Immunol 2009, 182:657-665.

91. Mozaffarian A, Brewer AW, Trueblood ES, Luzina IG, Todd NW, Atamas SP, Arnett HA: Mechanisms of oncostatin M-induced pulmonary inflammation and fibrosis. J Immunol 2008, 181:7243-7253.

92. Langdon C, Kerr C, Tong L, Richards CD: Oncostatin M regulates eotaxin expression in fibroblasts and eosinophilic inflammation in C57BL/6 mice. $\mathrm{J}$ Immunol 2003, 170:548-555.

93. Richards CD, Kerr C, Tong L, Langdon C: Modulation of extracellular matrix using adenovirus vectors. Biochem Soc Trans 2002, 30:107-111.

94. Ihn H, Tamaki K: Oncostatin M stimulates the growth of dermal fibroblasts via a mitogen-activated protein kinase-dependent pathway. J Immunol 2000, 165:2149-2155.

95. Ihn H, LeRoy EC, Trojanowska M: Oncostatin M stimulates transcription of the human alpha2(I) collagen gene via the Sp1/Sp3-binding site. J Biol Chem 1997, 272:24666-24672.

96. Scaffidi AK, Mutsaers SE, Moodley YP, McAnulty RJ, Laurent GJ, Thompson PJ, Knight DA: Oncostatin M stimulates proliferation, induces collagen production and inhibits apoptosis of human lung fibroblasts. $\mathrm{Br} \mathrm{J}$ Pharmacol 2002, 136:793-801.

97. Pechkovsky DV, Prasse A, Kollert F, Engel KM, Dentler J, Luttmann W, Friedrich K, Müller-Quernheim J, Zissel G: Alternatively activated alveolar macrophages in pulmonary fibrosis-mediator production and intracellular signal transduction. Clin Immunol 2010, 137:89-101.

98. Sun L, Louie MC, Vannella KM, Wilke CA, LeVine AM, Moore BB, Shanley TP: New concepts of IL-10-induced lung fibrosis: fibrocyte recruitment and M2 activation in a CCL2/CCR2 axis. Am J Physiol Lung Cell Mol Physiol 2011, 300:L341-L353.

99. Arai T, Abe K, Matsuoka H, Yoshida M, Mori M, Goya S, Kida H, Nishino K, Osaki T, Tachibana I, Kaneda Y, Hayashi S: Introduction of the interleukin10 gene into mice inhibited bleomycin-induced lung injury in vivo. Am J Physiol Lung Cell Mol Physiol 2000, 278:L914-L922.

100. García-Prieto E, González-López A, Cabrera S, Astudillo A, Gutiérrez-Fernández A, Fanjul-Fernandez M, Batalla-Solís E, Puente XS, Fueyo A, López-Otín C, Albaiceta GM: Resistance to bleomycin-induced lung fibrosis in MMP-8 deficient mice is mediated by interleukin-10. PLOS One 2010, 5:e13242.

101. Moore BB, Kolodsick JE, Thannickal VJ, Cooke K, Moore TA, Hogaboam C, Wilke CA, Toews GB: CCR2-mediated recruitment of fibrocytes to the alveolar space after fibrotic injury. Am J Pathol 2005, 166:675-684.

102. Zhang K, Gharaee-Kermani M, Jones ML, Warren JS, Phan SH: Lung monocyte chemoattractant protein-1 gene expression in bleomycininduced pulmonary fibrosis. J Immunol 1994, 153:4733-4741.

103. Johnston CJ, Williams JP, Okunieff $P$, Finkelstein JN: Radiation-induced pulmonary fibrosis: examination of chemokine and chemokine receptor families. Radiat Res 2002, 157:256-265.

104. Gharaee-Kermani M, Denholm EM, Phan SH: Costimulation of fibroblast collagen and transforming growth factor beta1 gene expression by monocyte chemoattractant protein-1 via specific receptors. J Biol Chem 1996, 271:17779-17784.

105. Liu X, Das AM, Seideman J, Griswold D, Afuh CN, Kobayashi T, Abe S, Fang Q, Hashimoto M, Kim H, Wang X, Shen L, Kawasaki S, Rennard SI: The CC chemokine ligand 2 (CCL2) mediates fibroblast survival through IL-6. Am J Respir Cell Mol Biol 2007, 37:121-128.

106. Gharaee-Kermani M, McCullumsmith RE, Charo IF, Kunkel SL, Phan SH: CCchemokine receptor 2 required for bleomycin-induced pulmonary fibrosis. Cytokine 2003, 24:266-276.

107. Rose CE Jr, Sung SS, Fu SM: Significant involvement of CCL2 (MCP-1) in inflammatory disorders of the lung. Microcirculation 2003, 10:273-288.

108. Inoshima I, Kuwano K, Hamada N, Hagimoto N, Yoshimi M, Maeyama T, Takeshita A, Kitamoto S, Egashira K, Hara N: Anti-monocyte chemoattractant protein-1 gene therapy attenuates pulmonary fibrosis in mice. Am J Physiol Lung Cell Mol Physiol 2004, 286:L1038-L1044.

109. Pochetuhen K, Luzina IG, Lockatell V, Todd NW, Atamas SP: Complex regulation of pulmonary inflammation and fibrosis by CCL18. Am J Pathol 2007, 171:428-437.

110. Atamas SP, Luzina IG, Choi J, Tsymbalyuk N, Carbonetti NH, Singh IS, Trojanowska M, Jimenez SA, White B: Pulmonary and activation-regulated chemokine stimulates collagen production in lung fibroblasts. Am J Respir Cell Mol Biol 2003, 29:743-749.

111. Luzina IG, Tsymbalyuk N, Choi J, Hasday JD, Atamas SP: CCL18-stimulated upregulation of collagen production in lung fibroblasts requires Sp1 signaling and basal Smad3 activity. J Cell Physiol 2006, 206:221-228.

112. Luzina IG, Highsmith K, Pochetuhen K, Nacu N, Rao JN, Atamas SP: PKCalpha mediates CCL18-stimulated collagen production in pulmonary fibroblasts. Am J Respir Cell Mol Biol 2006, 35:298-305.

113. Luzina IG, Papadimitriou JC, Anderson R, Pochetuhen K, Atamas SP: Induction of prolonged infiltration of T lymphocytes and transient $\mathrm{T}$ lymphocyte-dependent collagen deposition in mouse lungs following adenoviral gene transfer of CCL18. Arthritis Rheum 2006, 54:2643-2655.

114. Prasse A, Probst C, Bargagli E, Zissel G, Toews GB, Flaherty KR, Olschewski M, Rottoli P, Müller-Quernheim J: Serum CC-chemokine ligand 18 concentration predicts outcome in idiopathic pulmonary fibrosis. Am J Respir Crit Care Med 2009, 179:717-723.

115. Tiev KP, Hua-Huy T, Kettaneh A, Gain M, Duong-Quy S, Tolédano C, Cabane J, Dinh-Xuan AT: Serum CC chemokine ligand-18 predicts lung disease worsening in systemic sclerosis. Eur Respir J 2011, 38:1355-1360.

116. Ishida Y, Kimura A, Kondo T, Hayashi T, Ueno M, Takakura N, Matsushima K, Mukaida N: Essential roles of the CC chemokine ligand 3-CC chemokine receptor 5 axis in bleomycin-induced pulmonary fibrosis through regulation of macrophage and fibrocyte infiltration. Am J Pathol 2007, 170:843-854.

117. Yang X, Walton W, Cook DN, Hua X, Tilley S, Haskell CA, Horuk R, Blackstock AW, Kirby SL: The chemokine, CCL3, and its receptor, CCR1, mediate thoracic radiation-induced pulmonary fibrosis. Am J Respir Cell Mol Biol 2011, 45:127-135.

118. Smith RE, Strieter RM, Phan SH, Lukacs NW, Huffnagle GB, Wilke CA, Burdick MD, Lincoln P, Evanoff H, Kunkel SL: Production and function of murine macrophage inflammatory protein-1 alpha in bleomycin-induced lung injury. J Immunol 1994, 153:4704-4712.

119. Russo RC, Alessandri AL, Garcia CC, Cordeiro BF, Pinho V, Cassali GD, Proudfoot AE, Teixeira MM: Therapeutic effects of evasin-1, a chemokine binding protein, in bleomycin-induced pulmonary fibrosis. Am J Respir Cell Mol Biol 2011, 45:72-80.

120. Lama VN, Phan SH: The extrapulmonary origin of fibroblasts: stem/ progenitor cells and beyond. Proc Am Thorac Soc 2006, 3:373-376.

121. Andersson-Sjöland A, de Alba CG, Nihlberg K, Becerril C, Ramírez R, Pardo A, Westergren-Thorsson G, Selman M: Fibrocytes are a potential source of lung fibroblasts in idiopathic pulmonary fibrosis. Int J Biochem Cell Biol 2008, 40:2129-2140.

122. Phillips RJ, Burdick MD, Hong K, Lutz MA, Murray LA, Xue YY, Belperio JA, Keane MP, Strieter RM: Circulating fibrocytes traffic to the lungs in response to CXCL12 and mediate fibrosis. J Clin Invest 2004, 114:438-446.

123. Schrier DJ, Phan SH, McGarry BM: The effects of the nude (nu/nu) mutation on bleomycin-induced pulmonary fibrosis. Am Rev Respir Dis 1983, 127:614-617

124. Okazaki T, Nakao A, Nakano H, Takahashi F, Takahashi K, Shimozato O, Takeda K, Yagita H, Okumura K: Impairment of bleomycin-induced lung fibrosis in CD28-deficient mice. J Immunol 2001, 167:1977-1981.

125. Piguet PF, Collart MA, Grau GE, Kapanci Y, Vassalli P: Tumor necrosis factor/ cachectin plays a key role in bleomycin-induced pneumopathy and fibrosis. J Exp Med 1989, 170:655-663. 
126. Sharma SK, MacLean JA, Pinto C, Kradin RL: The effect of an anti-CD3 monoclonal antibody on bleomycin-induced lymphokine production and lung injury. Am J Respir Crit Care Med 1996, 154:193-200.

127. Chenivesse C, Chang Y, Azzaoui I, Ait Yahia S, Morales O, Plé C, Foussat A, Tonnel AB, Delhem N, Yssel H, Vorng H, Wallaert B, Tsicopoulos A. Pulmonary CCL18 recruits human regulatory T cells. J Immunol 2012, 189:128-37

128. Maggi E, Cosmi L, Liotta F, Romagnani P, Romagnani S, Annunziato F: Thymic regulatory T cells. Autoimmun Rev 2005, 4:579-586.

129. Kradin RL, Divertie MB, Colvin RB, Ramirez J, Ryu J, Carpenter HA, Bhan AK: Usual interstitial pneumonitis is a T-cell alveolitis. Clin Immunol Immunopathol 1986, 40:224-235.

130. Daniil Z, Kitsanta P, Kapotsis G, Mathioudaki M, Kollintza A, Karatza M, Milic Emili J, Roussos C, Papiris SA: CD8+ T lymphocytes in lung tissue from patients with idiopathic pulmonary fibrosis. Respir Res 2005, 6:81

131. Parra ER, Kairalla RA, Ribeiro de Carvalho CR, Eher E, Capelozzi VL: Inflammatory cell phenotyping of the pulmonary interstitium in idiopathic interstitial pneumonia. Respiration 2007, 74:159-169.

132. Marchal-Somme J, Uzunhan Y, Marchand-Adam S, Valeyre D, Soumelis V Crestani B, Soler P: Cutting edge: nonproliferating mature immune cells form a novel type of organized lymphoid structure in idiopathic pulmonary fibrosis. J Immunol 2006, 176:5735-5739.

133. Fireman E, Vardinon N, Burke M, Spizer S, Levin S, Endler A, Stav D, Topilsky M, Mann A, Schwarz Y, Kivity S, Greif J: Predictive value of response to treatment of T-lymphocyte subpopulations in idiopathic pulmonary fibrosis. Eur Respir J 1998, 11:706-711.

134. Pignatti P, Brunetti G, Moretto D, Yacoub MR, Fiori M, Balbi B, Balestrino A, Cervio G, Nava S, Moscato G: Role of the chemokine receptors CXCR3 and CCR4 in human pulmonary fibrosis. Am J Respir Crit Care Med 2006, 173:310-317.

135. Wells AU, Lorimer S, Majumdar S, Harrison NK, Corrin B, Black CM, Jeffery PK, du Bois RM: Fibrosing alveolitis in systemic sclerosis: increase in memory T-cells in lung interstitium. Eur Respir J 1995, 8:266-271.

136. Gilani SR, Vuga LJ, Lindell KO, Gibson KF, Xue J, Kaminski N, Valentine VG, Lindsay EK, George MP, Steele C, Duncan SR: CD28 down-regulation on circulating CD4 T-cells is associated with poor prognoses of patients with idiopathic pulmonary fibrosis. PLoS One 2010, 5:e8959.

137. Shimizu Y, Kuwabara H, Ono A, Higuchi S, Hisada T, Dobashi K, Utsugi M, Mita Y, Mori M: Intracellular Th1/Th2 balance of pulmonary CD4(+) T cells in patients with active interstitial pneumonia evaluated by serum KL-6. Immunopharmacol Immunotoxicol 2006, 28:295-304.

138. Atamas SP, Yurovsky W, Wise R, Wigley FM, Goter Robinson CJ, Henry P, Alms WJ, White B: Production of type 2 cytokines by CD8+ lung cells is associated with greater decline in pulmonary function in patients with systemic sclerosis. Arthritis Rheum 1999, 42:1168-1178.

139. Luzina IG, Atamas SP, Wise R, Wigley FM, Choi J, Xiao HQ, White B: Occurrence of an activated, profibrotic pattern of gene expression in lung CD8+ T cells from scleroderma patients. Arthritis Rheum 2003, 48:2262-2274

140. Popp W, Ritschka L, Scherak O, Braun O, Kolarz G, Rauscher H, Zwick H: Bronchoalveolar lavage in rheumatoid arthritis and secondary Sjogren's syndrome. Lung 1990, 168:221-231.

141. Sauty A, Rochat T, Schoch OD, Hamacher J, Kurt AM, Dayer JM, Nicod LP. Pulmonary fibrosis with predominant CD8 lymphocytic alveolitis and anti-Jo-1 antibodies. Eur Respir J 1997, 10:2907-2912

142. Kourakata H, Takada T, Suzuki E, Enomoto K, Saito I, Taguchi Y, Tsukada H, Nakano M, Arakawa M: Flowcytometric analysis of bronchoalveolar lavage fluid cells in polymyositis/dermatomyositis with interstitial pneumonia. Respirology 1999, 4:223-228.

143. Capelli A, Di Stefano A, Lusuardi M, Gnemmi I, Donner CF: Increased macrophage inflammatory protein-1alpha and macrophage inflammatory protein-1 beta levels in bronchoalveolar lavage fluid of patients affected by different stages of pulmonary sarcoidosis. Am J Respir Crit Care Med 2002, 165:236-241.

144. Bill JR, Mack DG, Falta MT, Maier LA, Sullivan AK, Joslin FG, Martin AK, Freed BM, Kotzin BL, Fontenot AP: Beryllium presentation to CD4+ T cells is dependent on a single amino acid residue of the MHC class II beta-chain. $J$ Immunol 2005, 175:7029-7037.

145. Murayama J, Yoshizawa Y, Ohtsuka M, Hasegawa S: Lung fibrosis in hypersensitivity pneumonitis. Association with CD4+ but not CD8+ cell dominant alveolitis and insidious onset. Chest 1993, 104:38-43.
146. Reynolds HY: Lung inflammation and fibrosis: an alveolar macrophagecentered perspective from the 1970s to 1980s. Am J Respir Crit Care Med 2005, 171:98-102.

147. Cantin AM, North SL, Fells GA, Hubbard RC, Crystal RG: Oxidant-mediated epithelial cell injury in idiopathic pulmonary fibrosis. J Clin Invest 1987, 79:1665-1673.

148. Bocchino M, Agnese S, Fagone E, Svegliati S, Grieco D, Vancheri C, Gabrielli A, Sanduzzi A, Avvedimento EV: Reactive oxygen species are required for maintenance and differentiation of primary lung fibroblasts in idiopathic pulmonary fibrosis. PLoS One 2010, 5:e14003.

149. Kiemle-Kallee J, Kreipe H, Radzun HJ, Parwaresch MR, Auerswald U, Magnussen H, Barth J: Alveolar macrophages in idiopathic pulmonary fibrosis display a more monocyte-like immunophenotype and an increased release of free oxygen radicals. Eur Respir $J$ 1991, 4:400-406.

150. Schaberg T, Rau M, Stephan H, Lode H: Increased number of alveolar macrophages expressing surface molecules of the CD11/CD18 family in sarcoidosis and idiopathic pulmonary fibrosis is related to the production of superoxide anions by these cells. Am Rev Respir Dis 1993, 147:1507-1513.

151. Ye Q, Dalavanga Y, Poulakis N, Sixt SU, Guzman J, Costabel U: Decreased expression of haem oxygenase-1 by alveolar macrophages in idiopathic pulmonary fibrosis. Eur Respir J 2008, 31:1030-1036.

152. Scotton CJ, Krupiczojc MA, Königshoff M, Mercer PF, Lee YC, Kaminski N, Morser J, Post JM, Maher TM, Nicholson AG, Moffatt JD, Laurent GJ, Derian CK, Eickelberg O, Chambers RC: Increased local expression of coagulation factor $\mathrm{X}$ contributes to the fibrotic response in human and murine lung injury. J Clin Invest 2009, 119:2550-2563.

153. Howell DC, Johns RH, Lasky JA, Shan B, Scotton CJ, Laurent GJ, Chambers $\mathrm{RC}$ : Absence of proteinase-activated receptor-1 signaling affords protection from bleomycin-induced lung inflammation and fibrosis. Am J Pathol 2005, 166:1353-1365.

154. Tani K, Ogushi F, Takahashi H, Kawano T, Endo T, Sone S: Thrombin stimulates platelet-derived growth factor release by alveolar macrophages in rats-significance in bleomycin-induced pulmonary fibrosis. J Med Invest 1997, 44:59-65.

155. Kopiński P, Balicka-Ślusarczyk B, Dyczek A, Szpechciński A, Przybylski G, Jarzemska A, Wandtke T, Jankowski M, Iwaniec T, Chorostowska-Wynimko J: Enhanced expression of Fas Ligand (FasL) in the lower airways of patients with fibrotic interstitial lung diseases (ILDs). Folia Histochem Cytobiol 2011, 49:636-645.

156. Martinet Y, Rom WN, Grotendorst GR, Martin GR, Crystal RG: Exaggerated spontaneous release of platelet-derived growth factor by alveolar macrophages from patients with idiopathic pulmonary fibrosis. $N$ Engl $J$ Med 1987, 317:202-209.

157. Nagaoka I, Trapnell BC, Crystal RG: Upregulation of platelet-derived growth factor-A and -B gene expression in alveolar macrophages of individuals with idiopathic pulmonary fibrosis. J Clin Invest 1990, 85:2023-2027.

158. Zhang Y, Lee TC, Guillemin B, Yu MC, Rom WN: Enhanced IL-1 beta and tumor necrosis factor-alpha release and messenger RNA expression in macrophages from idiopathic pulmonary fibrosis or after asbestos exposure. J Immunol 1993, 150:4188-4196.

159. Furuie $H$, Yamasaki $H$, Suga M, Ando M: Altered accessory cell function of alveolar macrophages: a possible mechanism for induction of Th2 secretory profile in idiopathic pulmonary fibrosis. Eur Respir J 1997, 10:787-794.

160. Büttner C, Skupin A, Reimann T, Rieber EP, Unteregger G, Geyer P, Frank KH: Local production of interleukin-4 during radiation-induced pneumonitis and pulmonary fibrosis in rats: macrophages as a prominent source of interleukin-4. Am J Respir Cell Mol Biol 1997, 17:315-325.

161. Prasse A, Pechkovsky DV, Toews GB, Jungraithmayr W, Kollert F, Goldmann T, Vollmer E, Müller-Quernheim J, Zissel G: A vicious circle of alveolar macrophages and fibroblasts perpetuates pulmonary fibrosis via CCL18. Am J Respir Crit Care Med 2006, 173:781-792.

162. Migliaccio CT, Buford MC, Jessop F, Holian A: The IL-4Ralpha pathway in macrophages and its potential role in silica-induced pulmonary fibrosis. J Leukoc Biol 2008, 83:630-639.

163. Mora AL, Torres-González E, Rojas M, Corredor C, Ritzenthaler J, Xu J, Roman J, Brigham K, Stecenko A: Activation of alveolar macrophages via the alternative pathway in herpesvirus-induced lung fibrosis. Am J Respir Cell Mol Biol 2006, 35:466-473. 
164. Murray LA, Chen Q, Kramer MS, Hesson DP, Argentieri RL, Peng X, Gulati M, Homer RJ, Russell T, van Rooijen N, Elias JA, Hogaboam CM, Herzog EL: TGF-beta driven lung fibrosis is macrophage dependent and blocked by Serum amyloid P. Int J Biochem Cell Biol 2011, 43:154-162.

165. Murray LA, Rosada R, Moreira AP, Joshi A, Kramer MS, Hesson DP, Argentieri RL, Mathai S, Gulati M, Herzog EL, Hogaboam CM: Serum amyloid P therapeutically attenuates murine bleomycin-induced pulmonary fibrosis via its effects on macrophages. PLoS One 2010, 5:e9683.

166. Wallace WA, Roberts SN, Caldwell H, Thornton E, Greening AP, Lamb D, Howie SE: Circulating antibodies to lung protein(s) in patients with cryptogenic fibrosing alveolitis. Thorax 1994, 49:218-224.

167. Wallace WA, Schofield JA, Lamb D, Howie SE: Localisation of a pulmonary autoantigen in cryptogenic fibrosing alveolitis. Thorax 1994, 49:1139-1145.

168. Yang Y, Fujita J, Bandoh S, Ohtsuki Y, Yamadori I, Yoshinouchi $T$, Ishida T: Detection of antivimentin antibody in sera of patients with idiopathic pulmonary fibrosis and non-specific interstitial pneumonia. Clin Exp Immunol 2002, 128:169-174.

169. Dobashi N, Fujita J, Ohtsuki Y, Yamadori I, Yoshinouchi T, Kamei T, Tokuda M, Hojo S, Okada H, Takahara J: Detection of anticytokeratin 8 antibody in the serum of patients with cryptogenic fibrosing alveolitis and pulmonary fibrosis associated with collagen vascular disorders. Thorax 1998, 53:969-974.

170. Fujita J, Dobashi N, Ohtsuki Y, Yamadori I, Yoshinouchi T, Kamei T, Tokuda M, Hojo S, Okada H, Takahara J: Elevation of anticytokeratin 19 antibody in sera of the patients with idiopathic pulmonary fibrosis and pulmonary fibrosis associated with collagen vascular disorders. Lung 1999, 177:311-319.

171. Feghali-Bostwick CA, Tsai CG, Valentine VG, Kantrow S, Stoner MW, Pilewsk JM, Gadgil A, George MP, Gibson KF, Choi AM, Kaminski N, Zhang Y, Duncan SR: Cellular and humoral autoreactivity in idiopathic pulmonary fibrosis. J Immunol 2007, 179:2592-2599.

172. Taillé C, Grootenboer-Mignot S, Boursier C, Michel L, Debray MP, Fagart J Barrientos L, Mailleux A, Cigna N, Tubach F, Marchal-Sommé J, Soler P, Chollet-Martin S, Crestani B: Identification of periplakin as a new target for autoreactivity in idiopathic pulmonary fibrosis. Am J Respir Crit Care Med 2011, 183:759-766

173. Sato S, Hasegawa M, Fujimoto M, Tedder TF, Takehara K: Quantitative genetic variation in CD19 expression correlates with autoimmunity. $\mathrm{J}$ Immunol 2000, 165:6635-6643.

174. Tsuchiya N, Kuroki K, Fujimoto M, Murakami Y, Tedder TF, Tokunaga K, Takehara K, Sato S: Association of a functional CD19 polymorphism with susceptibility to systemic sclerosis. Arthritis Rheum 2004, 50:4002-4007.

175. Yoshizaki A, Iwata Y, Komura K, Ogawa F, Hara T, Muroi E, Takenaka M, Shimizu K, Hasegawa M, Fujimoto M, Tedder TF, Sato S: CD19 regulates skin and lung fibrosis via Toll-like receptor signaling in a model of bleomycin-induced scleroderma. Am J Pathol 2008, 172:1650-1663.

176. Komura K, Yanaba K, Horikawa M, Ogawa F, Fujimoto M, Tedder TF, Sato S: CD19 regulates the development of bleomycin-induced pulmonary fibrosis in a mouse model. Arthritis Rheum 2008, 58:3574-3584

177. Arras M, Huaux F, Vink A, Delos M, Coutelier JP, Many MC, Barbarin V, Renauld JC, Lison D: Interleukin-9 reduces lung fibrosis and type 2 immune polarization induced by silica particles in a murine model. Am J Respir Cell Mol Biol 2001, 24:368-375.

178. Arras M, Louahed J, Simoen V, Barbarin V, Misson P, van den Brûle S, Delos M, Knoops L, Renauld JC, Lison D, Huaux F: B lymphocytes are critical for lung fibrosis control and prostaglandin E2 regulation in IL-9 transgenic mice. Am J Respir Cell Mol Biol 2006, 34:573-580.

179. Hess S, Rensing-Ehl A, Schwabe R, Bufler P, Engelmann H: CD40 function in nonhematopoietic cells. Nuclear factor kappa B mobilization and induction of IL-6 production. J Immunol 1995, 155:4588-4595.

180. Fries KM, Sempowski GD, Gaspari AA, Blieden T, Looney RJ, Phipps RP: CD40 expression by human fibroblasts. Clin Immunol Immunopathol 1995, 77:42-51.

181. Yellin MJ, Winikoff S, Fortune SM, Baum D, Crow MK, Lederman S, Chess L: Ligation of CD40 on fibroblasts induces CD54 (ICAM-1) and CD106 (VCAM-1) up-regulation and IL-6 production and proliferation. J Leukocyte Biol 1995, 58:209.

182. Sempowski GD, Chess PR, Phipps RP: CD40 is a functional activation antigen and B7-independent $T$ cell costimulatory molecule on normal human lung fibroblasts. J Immunol 1997, 158:4670-4677.
183. Zhang-Hoover J, Sutton A, Stein-Streilein J: CD40/CD40 ligand interactions are critical for elicitation of autoimmune-mediated fibrosis in the lung. $\mathrm{J}$ Immunol 2001, 166:3556-3563.

184. Adawi A, Zhang Y, Baggs R, Rubin P, Williams J, Finkelstein J, Phipps RP: Blockade of CD40-CD40 ligand interactions protects against radiationinduced pulmonary inflammation and fibrosis. Clin Immunol Immunopathol 1998, 89:222-230.

185. Adawi A, Zhang Y, Baggs R, Finkelstein J, Phipps RP: Disruption of the CD40-CD40 ligand system prevents an oxygen-induced respiratory distress syndrome. Am J Pathol 1998, 152:651-657.

186. Henn V, Slupsky JR, Gräfe M, Anagnostopoulos I, Förster R, Müller-Berghaus $\mathrm{G}$, Kroczek RA: CD40 ligand on activated platelets triggers an inflammatory reaction of endothelial cells. Nature 1998, 391:591-594.

187. Pinchuk LM, Klaus SJ, Magaletti DM, Pinchuk GV, Norsen JP, Clark EA: Functional CD40 ligand expressed by human blood dendritic cells is upregulated by CD40 ligation. J Immunol 1996, 157:4363-4370

188. Kaufman J, Sime PJ, Phipps RP: Expression of CD154 (CD40 ligand) by human lung fibroblasts: differential regulation by IFN-gamma and IL-13, and implications for fibrosis. J Immunol 2004, 172:1862-1871.

189. Kaufman J, Graf BA, Leung EC, Pollock SJ, Koumas L, Reddy SY, Blieden TM Smith TJ, Phipps RP: Fibroblasts as sentinel cells: role of the CDcd40CDcd40 ligand system in fibroblast activation and lung inflammation and fibrosis. Chest 2001, 120(1 Suppl):53S-55S.

190. Hagimoto N, Kuwano K, Nomoto Y, Kunitake R, Hara N: Apoptosis and expression of Fas/Fas ligand mRNA in bleomycin-induced pulmonary fibrosis in mice. Am J Respir Cell Mol Biol 1997, 16:91-101.

191. Golan-Gerstl R, Wallach-Dayan SB, Amir G, Breuer R: Epithelial cell apoptosis by fas ligand-positive myofibroblasts in lung fibrosis. Am J Respir Cell Mol Biol 2007, 36:270-275.

192. Hagimoto N, Kuwano K, Miyazaki H, Kunitake R, Fujita M, Kawasaki M, Kaneko Y, Hara N: Induction of apoptosis and pulmonary fibrosis in mice in response to ligation of Fas antigen. Am J Respir Cell Mol Biol 1997 $17: 272-278$

193. Matute-Bello G, Winn RK, Jonas M, Chi EY, Martin TR, Liles WC: Fas (CD95) induces alveolar epithelial cell apoptosis in vivo: implications for acute pulmonary inflammation. Am J Pathol 2001, 158:153-161.

194. Kuwano K, Hagimoto N, Kawasaki M, Yatomi T, Nakamura N, Nagata S, Suda T, Kunitake R, Maeyama T, Miyazaki H, Hara N: Essential roles of the Fas-Fas ligand pathway in the development of pulmonary fibrosis. J Clin Invest 1999, 104:13-19.

195. Hao Z, Hampel B, Yagita H, Rajewsky K: T cell-specific ablation of Fas leads to Fas ligand-mediated lymphocyte depletion and inflammatory pulmonary fibrosis. J Exp Med 2004, 199:1355-1365.

196. Bühling F, Wille A, Röcken C, Wiesner O, Baier A, Meinecke I, Welte T, Pap T: Altered expression of membrane-bound and soluble CD95/Fas contributes to the resistance of fibrotic lung fibroblasts to FasL induced apoptosis. Respir Res 2005, 6:37.

197. Frankel SK, Cosgrove GP, Cha SI, Cool CD, Wynes MW, Edelman BL, Brown KK, Riches DW: TNF-alpha sensitizes normal and fibrotic human lung fibroblasts to Fas-induced apoptosis. Am J Respir Cell Mol Biol 2006, 34:293-304.

198. Kuwano K, Miyazaki H, Hagimoto N, Kawasaki M, Fujita M, Kunitake R, Kaneko Y, Hara N: The involvement of Fas-Fas ligand pathway in fibrosing lung diseases. Am J Respir Cell Mol Biol 1999, 20:53-60.

199. Maeyama T, Kuwano K, Kawasaki M, Kunitake R, Hagimoto N, Matsuba T, Yoshimi M, Inoshima I, Yoshida K, Hara N: Upregulation of Fas-signalling molecules in lung epithelial cells from patients with idiopathic pulmonary fibrosis. Eur Respir J 2001, 17:180-189.

200. Kuwano K, Kawasaki M, Maeyama T, Hagimoto N, Nakamura N, Shirakawa K, Hara N: Soluble form of fas and fas ligand in BAL fluid from patients with pulmonary fibrosis and bronchiolitis obliterans organizing pneumonia. Chest 2000, 118:451-458.

201. Kuwano K, Maeyama T, Inoshima I, Ninomiya K, Hagimoto N, Yoshimi M, Fujita M, Nakamura N, Shirakawa K, Hara N: Increased circulating levels of soluble Fas ligand are correlated with disease activity in patients with fibrosing lung diseases. Respirology 2002, 7:15-21.

202. Hyytiäinen M, Penttinen C, Keski-Oja J: Latent TGF-beta binding proteins: extracellular matrix association and roles in TGF-beta activation. Crit Rev Clin Lab Sci 2004, 41:233-264.

203. Goodwin A, Jenkins G: Role of integrin-mediated TGFbeta activation in the pathogenesis of pulmonary fibrosis. Biochem Soc Trans 2009, 37:849-854. 
204. Weber GF, Bjerke MA, DeSimone DW: Integrins and cadherins join forces to form adhesive networks. J Cell Sci 2011, 124:1183-1193.

205. Ye F, Kim C, Ginsberg MH: Reconstruction of integrin activation. Blood 2012, 119:26-33.

206. Munger JS, Huang X, Kawakatsu H, Griffiths MJ, Dalton SL, Wu J, Pittet JF, Kaminski N, Garat C, Matthay MA, Rifkin DB, Sheppard D: The integrin alpha $v$ beta 6 binds and activates latent TGF beta 1: a mechanism for regulating pulmonary inflammation and fibrosis. Cell 1999, 96:319-328.

207. Puthawala K, Hadjiangelis N, Jacoby SC, Bayongan E, Zhao Z, Yang Z, Devitt ML, Horan GS, Weinreb PH, Lukashev ME, Violette SM, Grant KS, Colarossi C, Formenti SC, Munger JS: Inhibition of integrin alpha(v)beta6, an activator of latent transforming growth factor-beta, prevents radiation-induced lung fibrosis. Am J Respir Crit Care Med 2008, 177:82-90.

208. Horan GS, Wood S, Ona V, Li DJ, Lukashev ME, Weinreb PH, Simon KJ, Hahm K, Allaire NE, Rinaldi NJ, Goyal J, Feghali-Bostwick CA, Matteson EL, O'Hara C, Lafyatis R, Davis GS, Huang X, Sheppard D, Violette SM: Partial inhibition of integrin alpha(v)beta6 prevents pulmonary fibrosis without exacerbating inflammation. Am J Respir Crit Care Med 2008, 177:56-65

209. Kitamura H, Cambier S, Somanath S, Barker T, Minagawa S, Markovics J Goodsell A, Publicover J, Reichardt L, Jablons D, Wolters P, Hill A, Marks JD, Lou J, Pittet JF, Gauldie J, Baron JL, Nishimura SL: Mouse and human lung fibroblasts regulate dendritic cell trafficking, airway inflammation, and fibrosis through integrin av $\beta 8$-mediated activation of TGF- $\beta$. J Clin Invest 2011, 121:2863-2875.

210. Fjellbirkeland L, Cambier S, Broaddus VC, Hill A, Brunetta P, Dolganov G, Jablons D, Nishimura SL: Integrin alphavbeta8-mediated activation of transforming growth factor-beta inhibits human airway epithelial proliferation in intact bronchial tissue. Am J Pathol 2003, 163:533-542.

211. Neurohr C, Nishimura SL, Sheppard D: Activation of transforming growth factor-beta by the integrin alphavbeta8 delays epithelial wound closure. Am J Respir Cell Mol Biol 2006, 35:252-259.

212. Kim KK, Wei Y, Szekeres C, Kugler MC, Wolters PJ, Hill ML, Frank JA Brumwell AN, Wheeler SE, Kreidberg JA, Chapman HA: Epithelial cell alpha3beta1 integrin links beta-catenin and Smad signaling to promote myofibroblast formation and pulmonary fibrosis. J Clin Invest 2009, 119:213-224.

213. Borok Z: Role for alpha3 integrin in EMT and pulmonary fibrosis. J Clin Invest 2009, 119:7-10.

214. Luzina IG, Todd NW, Nacu N, Lockatell V, Choi J, Hummers LK, Atamas SP: Regulation of pulmonary inflammation and fibrosis through expression of integrins alphaVbeta3 and alphaVbeta5 on pulmonary T lymphocytes. Arthritis Rheum 2009, 60:1530-1539.

215. Kilshaw PJ: Alpha E beta 7. Mol Pathol 1999, 52:203-207.

216. Braun RK, Sterner-Kock A, Kilshaw PJ, Ferrick DA, Giri SN: Integrin alpha E beta 7 expression on BAL CD4+, CD8+, and gamma delta T-cells in bleomycin-induced lung fibrosis in mouse. Eur Respir J 1996, 9:673-679.

217. Rihs S, Walker C, Virchow JC Jr, Boer C, Kroegel C, Giri SN, Braun RK: Differential expression of alpha $E$ beta 7 integrins on bronchoalveolar lavage $T$ lymphocyte subsets: regulation by alpha 4 beta 1-integrin crosslinking and TGF-beta. Am J Respir Cell Mol Biol 1996, 15:600-610.

218. Vajkoczy P, Laschinger M, Engelhardt B: Alpha4-integrin-VCAM-1 binding mediates $G$ protein-independent capture of encephalitogenic T cell blasts to CNS white matter microvessels. J Clin Invest 2001, 108:557-565.

219. Wang Q, Wang Y, Hyde DM, Gotwals PJ, Lobb RR, Ryan ST, Giri SN: Effect of antibody against integrin alpha4 on bleomycin-induced pulmonary fibrosis in mice. Biochem Pharmacol 2000, 60:1949-1958.

220. Jokinen J, Dadu E, Nykvist $P$, Käpylä J, White DJ, Ivaska J, Vehviläinen $P$, Reunanen $\mathrm{H}$, Larjava H, Häkkinen L, Heino J: Integrin-mediated cell adhesion to type I collagen fibrils. J Biol Chem 2004, 279:31956-31963.

221. Xia H, Diebold D, Nho R, Perlman D, Kleidon J, Kahm J, Avdulov S, Peterson $M$, Nerva J, Bitterman P, Henke C: Pathological integrin signaling enhances proliferation of primary lung fibroblasts from patients with idiopathic pulmonary fibrosis. J Exp Med 2008, 205:1659-1672.

222. Wipff PJ, Rifkin DB, Meister JJ, Hinz B: Myofibroblast contraction activates latent TGF-beta1 from the extracellular matrix. J Cell Biol 2007, 179:1311-1323

223. Zhou Y, Hagood JS, Murphy-Ullrich JE: Thy-1 expression regulates the ability of rat lung fibroblasts to activate transforming growth factor-beta in response to fibrogenic stimuli. Am J Pathol 2004, 165:659-669.

224. Hagood JS, Prabhakaran P, Kumbla P, Salazar L, MacEwen MW, Barker TH, Ortiz LA, Schoeb T, Siegal GP, Alexander CB, Pardo A, Selman M: Loss of fibroblast Thy- 1 expression correlates with lung fibrogenesis. Am J Pathol 2005, 167:365-379

225. Zhou Y, Hagood JS, Lu B, Merryman WD, Murphy-Ullrich JE: Thy-1-integrin alphav beta5 interactions inhibit lung fibroblast contraction-induced latent transforming growth factor-beta1 activation and myofibroblast differentiation. J Biol Chem 2010, 285:22382-22393.

226. Asano $Y$, Ihn $H$, Jinnin M, Mimura $Y$, Tamaki $K$ : Involvement of alphavbeta5 integrin in the establishment of autocrine TGF-beta signaling in dermal fibroblasts derived from localized scleroderma. J Invest Dermatol 2006, 126:1761-1769.

227. Asano Y, Ihn H, Yamane K, Kubo M, Tamaki K: Increased expression levels of integrin alphavbeta5 on scleroderma fibroblasts. Am J Pathol 2004, 164:1275-1292.

228. Asano $\mathrm{Y}$, Ihn H, Yamane $\mathrm{K}$, Jinnin M, Tamaki K: Increased expression of integrin alphavbeta5 induces the myofibroblastic differentiation of dermal fibroblasts. Am J Pathol 2006, 168:499-510.

229. Fredberg U, Stengaard-Pedersen K: Chronic tendinopathy tissue pathology, pain mechanisms, and etiology with a special focus on inflammation. Scand J Med Sci Sports 2008, 18:3-15.

230. Schulze-Tanzil G, Al-Sadi O, Wiegand E, Ertel W, Busch C, Kohl B, Pufe T: The role of pro-inflammatory and immunoregulatory cytokines in tendon healing and rupture: new insights. Scand J Med Sci Sports 2011, 21:337-351.

231. Arvin B, Neville LF, Barone FC, Feuerstein GZ: The role of inflammation and cytokines in brain injury. Neurosci Biobehav Rev 1996, 20:445-452.

232. Ghirnikar RS, Lee YL, Eng LF: Inflammation in traumatic brain injury: role of cytokines and chemokines. Neurochem Res 1998, 23:329-340.

233. Helmy A, De Simoni MG, Guilfoyle MR, Carpenter KL, Hutchinson PJ: Cytokines and innate inflammation in the pathogenesis of human traumatic brain injury. Prog Neurobiol 2011, 95:352-372.

234. Keatings VM, Jatakanon A, Worsdell YM, Barnes PJ: Effects of inhaled and oral glucocorticoids on inflammatory indices in asthma and COPD. Am J Respir Crit Care Med 1997, 155:542-548.

235. Barnes PJ: Glucocorticosteroids: current and future directions. $\mathrm{Br} J$ Pharmacol 2011, 163:29-43.

236. Suissa S, Barnes PJ: Inhaled corticosteroids in COPD: the case against. Eur Respir J 2009, 34:13-16

237. Calverley PM, Anderson JA, Celli B, Ferguson GT, Jenkins C, Jones PW, Yates JC, Vestbo J, TORCH investigators: Salmeterol and fluticasone propionate and survival in chronic obstructive pulmonary disease. N Engl J Med 2007, 356:775-789.

238. Yang IA, Fong KM, Sim EH, Black PN, Lasserson TJ: Inhaled corticosteroids for stable chronic obstructive pulmonary disease. Cochrane Database Syst Rev 2007, 2:CD002991.

239. Culpitt SV, Maziak W, Loukidis S, Nightingale JA, Matthews JL, Barnes PJ: Effect of high dose inhaled steroid on cells, cytokines, and proteases in induced sputum in chronic obstructive pulmonary disease. Am J Respir Crit Care Med 1999, 160:1635-1639.

240. Loppow D, Schleiss MB, Kanniess F, Taube C, Jörres RA, Magnussen H: In patients with chronic bronchitis a four week trial with inhaled steroids does not attenuate airway inflammation. Respir Med 2001, 95:115-121.

241. Hattotuwa KL, Gizycki MJ, Ansari TW, Jeffery PK, Barnes NC: The effects of inhaled fluticasone on airway inflammation in chronic obstructive pulmonary disease: a double-blind, placebo-controlled biopsy study. Am J Respir Crit Care Med 2002, 165:1592-1596.

242. Leung DY, Martin RJ, Szefler SJ, Sher ER, Ying S, Kay AB, Hamid Q: Dysregulation of interleukin 4, interleukin 5, and interferon gamma gene expression in steroid-resistant asthma. J Exp Med 1995, 181:33-40.

243. Kay AB, Diaz P, Carmicheal J, Grant IW: Corticosteroid-resistant chronic asthma and monocyte complement receptors. Clin Exp Immunol 1981 44:576-580

244. Poznansky MC, Gordon AC, Douglas JG, Krajewski AS, Wyllie AH, Grant IW: Resistance to methylprednisolone in cultures of blood mononuclear cells from glucocorticoid-resistant asthmatic patients. Clin Sci (Lond) 1984, 67:639-645.

245. Corrigan CJ, Brown PH, Barnes NC, Tsai JJ, Frew AJ, Kay AB: Glucocorticoid resistance in chronic asthma. Peripheral blood T lymphocyte activation and comparison of the T lymphocyte inhibitory effects of glucocorticoids and cyclosporin A. Am Rev Respir Dis 1991, 144:1026-1032.

246. Yim RP, Koumbourlis AC. Steroid-resistant asthma. Paediatr Respir Rev 2012, 13:172-7. 
247. Yang M, Kumar RK, Hansbro PM, Foster PS. Emerging roles of pulmonary macrophages in driving the development of severe asthma. J Leukoc Biol 2012, 91:557-69.

248. Sliwinska-Stanczyk P, Pazdur J, Ziolkowska M, Jaworski J, KaminskaTchorzewska E, Lacki JK: The effect of methylprednisolone on proliferation of PBMCs obtained from steroid-sensitive and steroid-resistant rheumatoid arthritis patients. Scand J Rheumatol 2007, 36:167-171.

249. Seki M, Ushiyama C, Seta N, Abe K, Fukazawa T, Asakawa J, Takasaki Y, Hashimoto $\mathrm{H}$ : Apoptosis of lymphocytes induced by glucocorticoids and relationship to therapeutic efficacy in patients with systemic lupus erythematosus. Arthritis Rheum 1998, 41:823-830.

250. Farrell RJ, Kelleher D: Glucocorticoid resistance in inflammatory bowel disease. J Endocrinol 2003, 178:339-346.

251. Hearing SD, Norman M, Probert CS, Haslam N, Dayan CM: Predicting therapeutic outcome in severe ulcerative colitis by measuring in vitro steroid sensitivity of proliferating peripheral blood lymphocytes. Gut 1999, 45:382-388.

252. Donn R, Berry A, Stevens A, Farrow S, Betts J, Stevens R, Clayton C, Wang J, Warnock L, Worthington J, Scott L, Graham S, Ray D: Use of gene expression profiling to identify a novel glucocorticoid sensitivity determining gene, BMPRII. FASEB J 2007, 21:402-414.

253. Irusen E, Matthews JG, Takahashi A, Barnes PJ, Chung KF, Adcock IM: p38 Mitogen-activated protein kinase-induced glucocorticoid receptor phosphorylation reduces its activity: role in steroid-insensitive asthma. J Allergy Clin Immunol 2002, 109:649-657.

254. Bhavsar P, Hew M, Khorasani N, Torrego A, Barnes PJ, Adcock I, Chung KF: Relative corticosteroid insensitivity of alveolar macrophages in severe asthma compared with non-severe asthma. Thorax 2008, 63:784-790.

255. Galigniana MD, Piwien-Pilipuk G, Assreuy J: Inhibition of glucocorticoid receptor binding by nitric oxide. Mol Pharmacol 1999, 55:317-323.

256. Loke TK, Mallett KH, Ratoff J, O'Connor BJ, Ying S, Meng Q, Soh C, Lee TH, Corrigan CJ: Systemic glucocorticoid reduces bronchial mucosal activation of activator protein 1 components in glucocorticoid-sensitive but not glucocorticoid-resistant asthmatic patients. J Allergy Clin Immunol 2006, 118:368-375

257. Ito K, Yamamura S, Essilfie-Quaye S, Cosio B, Ito M, Barnes PJ, Adcock IM: Histone deacetylase 2-mediated deacetylation of the glucocorticoid receptor enables NF-kappaB suppression. J Exp Med 2006, 203:7-13.

258. Ito K, Ito M, Elliott WM, Cosio B, Caramori G, Kon OM, Barczyk A, Hayashi S, Adcock IM, Hogg JC, Barnes PJ: Decreased histone deacetylase activity in chronic obstructive pulmonary disease. N Engl J Med 2005, 352:1967-1976

259. Hew M, Bhavsar P, Torrego A, Meah S, Khorasani N, Barnes PJ, Adcock I, Chung KF: Relative corticosteroid insensitivity of peripheral blood mononuclear cells in severe asthma. Am J Respir Crit Care Med 2006, 174:134-141.

260. Ito K, Hanazawa T, Tomita K, Barnes PJ, Adcock IM: Oxidative stress reduces histone deacetylase 2 activity and enhances IL-8 gene expression: role of tyrosine nitration. Biochem Biophys Res Commun 2004, 315:240-245.

261. Marwick JA, Caramori G, Casolari P, Mazzoni F, Kirkham PA, Adcock IM, Chung KF, Papi A: A role for phosphoinositol 3-kinase delta in the impairment of glucocorticoid responsiveness in patients with chronic obstructive pulmonary disease. J Allergy Clin Immunol 2010, 125:1146-1153.

262. Marwick JA, Caramori G, Stevenson CS, Casolari P, Jazrawi E, Barnes PJ, Ito K, Adcock IM, Kirkham PA, Papi A: Inhibition of PI3Kdelta restores glucocorticoid function in smoking-induced airway inflammation in mice. Am J Respir Crit Care Med 2009, 179:542-548.

263. Kinnula VL, Crapo JD: Superoxide dismutases in the lung and human lung diseases. Am J Respir Crit Care Med 2003, 167:1600-1619.

264. Crapo JD: Oxidative stress as an initiator of cytokine release and cell damage. Eur Respir J Suppl 2003, 44(suppl):4s-6s

265. Griffith B, Pendyala S, Hecker L, Lee PJ, Natarajan V, Thannickal VJ: NOX enzymes and pulmonary disease. Antioxid Redox Signal 2009, 11:2505-2516.

266. Kinnula VL, Fattman CL, Tan RJ, Oury TD: Oxidative stress in pulmonary fibrosis: a possible role for redox modulatory therapy. Am J Respir Crit Care Med 2005, 172:417-422.

267. Bartz RR, Piantadosi CA: Clinical review: oxygen as a signaling molecule. Crit Care 2010, 14:234.

268. Bedard K, Krause K: The NOX family of ROS-generating NADPH oxidases: physiology and pathophysiology. Physiol Rev 2007, 87:245-313.
269. Griendling KK: NADPH oxidases: new regulators of old functions. Antioxid Redox Signal 2006, 8:1443-1445

270. Hecker L, Vittal R, Jones T, Jagirdar R, Luckhardt TR, Horowitz JC, Pennathur S, Martinez FJ, Thannickal VJ: NADPH oxidase-4 mediates myofibroblast activation and fibrogenic responses to lung injury. Nat Med 2009, 15:1077-1081

271. Rahman I, MacNee W: Oxidative stress and regulation of glutathione in lung inflammation. Eur Respir J 2000, 16:534-554.

272. Cantin AM, North SL, Hubbard RC, Crystal RG: Normal alveolar epithelial lining fluid contains high levels of glutathione. J Appl Physio/ 1987, 63:152-157

273. Cantin AM, Hubbard RC, Crystal RG: Glutathione deficiency in the epithelial lining fluid of the lower respiratory tract in idiopathic pulmonary fibrosis. Am Rev Respir Dis 1989, 139:370-372.

274. Behr J, Degenkolb B, Krombach F, Vogelmeier C: Intracellular glutathione and bronchoalveolar cells in fibrosing alveolitis: effects of $\mathrm{N}$ acetylcysteine. Eur Respir J 2002, 19:906-911.

275. Behr J, Degenkolb B, Maier K, Braun B, Beinert T, Krombach F, Vogelmeier C, Fruhmann G: Increased oxidation of extracellular glutathione by bronchoalveolar inflammatory cells in diffuse fibrosing alveolitis. Eur Respir J 1995, 8:1286-1292.

276. Meyer A, Buhl R, Magnussen $H$ : The effect of oral N-acetylcysteine on lung glutathione levels in idiopathic pulmonary fibrosis. Eur Respir J 1994 7:431-436.

277. Tiitto LH, Peltoniemi MJ, Kaarteenaho-Wiik RL, Soini YM, Pääkkö PK, Sormunen RT, Kinnula VL: Cell-specific regulation of gammaglutamylcysteine synthetase in human interstitial lung diseases. Hum Pathol 2004, 35:832-839.

278. Kinnula VL, Hodgson UA, Lakari EK, Tan RJ, Sormunen RT, Soini YM, Kakko SJ, Laitinen TH, Oury TD, Pääkkö PK: Extracellular superoxide dismutase has a highly specific localization in idiopathic pulmonary fibrosis/usual interstitial pneumonia. Histopathology 2006, 49:66-74.

279. Pache JC, Carnesecchi S, Deffert C, Donati Y, Herrmann FR, BarazzoneArgiroffo C, Krause KH: NOX4 is expressed in thickened pulmonary arteries in idiopathic pulmonary fibrosis. Nat Med 2011, 17:31-32.

280. Carnesecchi S, Deffert C, Donati Y, Basset O, Hinz B, Preynat-Seauve O, Guichard C, Arbiser JL, Banfi B, Pache JC, Barazzone-Argiroffo C, Krause KH: A Key Role for NOX4 in Epithelial Cell Death During Development of Lung Fibrosis. Antioxid Redox Signal 2011, 15:607-619.

281. Serrano-Mollar A, Closa D, Prats N, Blesa S, Martinez-Losa M, Cortijo J, Estrela $J M$, Morcillo EJ, Bulbena O: In vivo antioxidant treatment protects against bleomycin-induced lung damage in rats. Br J Pharmacol 2003, 138:1037-1048.

282. Mata M, Ruíz A, Cerdá M, Martinez-Losa M, Cortijo J, Santangelo F, SerranoMollar A, Llombart-Bosch A, Morcillo EJ: Oral N-acetylcysteine reduces bleomycin-induced lung damage and mucin Muc5ac expression in rats. Eur Respir J 2003, 22:900-905.

283. Hagiwara SI, Ishii Y, Kitamura S: Aerosolized administration of Nacetylcysteine attenuates lung fibrosis induced by bleomycin in mice. Am J Respir Crit Care Med 2000, 162:225-231.

284. Oury TD, Thakker K, Menache M, Chang LY, Crapo JD, Day BJ: Attenuation of bleomycin-induced pulmonary fibrosis by a catalytic antioxidant metalloporphyrin. Am J Respir Cell Mol Biol 2001, 25:164-169.

285. Fattman CL, Chang LY, Termin TA, Petersen L, Enghild JJ, Oury TD: Enhanced bleomycin-induced pulmonary damage in mice lacking extracellular superoxide dismutase. Free Radic Biol Med 2003, 35:763-771.

286. Bowler RP, Nicks M, Warnick K, Crapo JD: Role of extracellular superoxide dismutase in bleomycin-induced pulmonary fibrosis. Am J Physiol Lung Cell Mol Physiol 2002, 282:L719-L726.

287. Cho HY, Reddy SP, Yamamoto M, Kleeberger SR: The transcription factor NRF2 protects against pulmonary fibrosis. FASEB J 2004, 18:1258-1260.

288. Cantin AM, Larivée P, Bégin RO: Extracellular glutathione suppresses human lung fibroblast proliferation. Am J Respir Cell Mol Biol 1990, 3:79-85.

289. Ramirez A, Ramadan B, Ritzenthaler JD, Rivera HN, Jones DP, Roman J: Extracellular cysteine/cystine redox potential controls lung fibroblast proliferation and matrix expression through upregulation of transforming growth factor-beta. Am J Physiol Lung Cell Mol Physiol 2007, 293:L972-L981.

290. Barcellos-Hoff MH, Dix TA: Redox-mediated activation of latent transforming growth factor-beta 1. Mol Endocrinol 1996, 10:1077-1083. 
291. Thannickal VJ, Fanburg BL: Activation of an $\mathrm{H}_{2} \mathrm{O}_{2}$-generating NADH oxidase in human lung fibroblasts by transforming growth factor beta 1 . J Biol Chem 1995, 270:30334-30338

292. Arsalane K, Dubois CM, Muanza T, Bégin R, Boudreau F, Asselin C, Cantin AM: Transforming growth factor-beta1 is a potent inhibitor of glutathione synthesis in the lung epithelial cell line A549: transcriptional effect on the GSH rate-limiting enzyme gamma-glutamylcysteine synthetase. Am J Respir Cell Mol Biol 1997, 17:599-607.

293. Liu RM, Liu Y, Forman HJ, Olman M, Tarpey MM: Glutathione regulates transforming growth factor-beta-stimulated collagen production in fibroblasts. Am J Physiol Lung Cell Mol Physiol 2004, 286:L121-L128.

294. Felton VM, Borok Z, Willis BC: N-acetylcysteine inhibits alveolar epithelialmesenchymal transition. Am J Physiol Lung Cell Mol Physiol 2009, 297: L805-L812.

295. Waghray M, Cui Z, Horowitz JC, Subramanian IM, Martinez FJ, Toews GB, Thannickal VJ: Hydrogen peroxide is a diffusible paracrine signal for the induction of epithelial cell death by activated myofibroblasts. FASEB $J$ 2005, 19:854-856.

296. Sugiura H, Ichikawa T, Liu X, Kobayashi T, Wang XQ, Kawasaki S, Togo S, Kamio K, Mao L, Ann Y, Ichinose M, Rennard Sl: N-acetyl-L-cysteine inhibits TGF-beta1-induced profibrotic responses in fibroblasts. Pulm Pharmacol Ther 2009, 22:487-491.

297. Meurer SK, Lahme B, Tihaa L, Weiskirchen R, Gressner AM: N-acetyl-Lcysteine suppresses TGF-beta signaling at distinct molecular steps: the biochemical and biological efficacy of a multifunctional, antifibrotic drug. Biochem Pharmacol 2005, 70:1026-1034.

298. Lichtenberger FJ, Montague C, Hunter M, Frambach G, Marsh CB: NAC and DTT promote TGF-beta1 monomer formation: demonstration of competitive binding. J Inflamm (Lond) 2006, 3:7.

299. Sturrock A, Cahill B, Norman K, Huecksteadt TP, Hill K, Sanders K, Karwande SV, Stringham JC, Bull DA, Gleich M, Kennedy TP, Hoidal JR: Transforming growth factor-beta1 induces Nox4 NAD(P)H oxidase and reactive oxygen species-dependent proliferation in human pulmonary artery smooth muscle cells. Am J Physiol Lung Cell Mol Physiol 2006, 290:L661-L673.

300. Ismail S, Sturrock A, Wu P, Cahill B, Norman K, Huecksteadt T, Sanders K, Kennedy T, Hoidal J: NOX4 mediates hypoxia-induced proliferation of human pulmonary artery smooth muscle cells: the role of autocrine production of transforming growth factor-\{beta\}1 and insulin-like growth factor binding protein-3. Am J Physiol Lung Cell Mol Physiol 2009, 296: L489-L499.

301. Bondi CD, Manickam N, Lee DY, Block K, Gorin Y, Abboud HE, Barnes JL: $\mathrm{NAD}(\mathrm{P}) \mathrm{H}$ oxidase mediates TGF-beta1-induced activation of kidney myofibroblasts. J Am Soc Nephrol 2010, 21:93-102.

302. Demedts M, Behr J, Buhl R, Costabel U, Dekhuijzen R, Jansen HM, MacNee W, Thomeer M, Wallaert B, Laurent F, Nicholson AG, Verbeken EK, Verschakelen J, Flower CD, Capron F, Petruzzelli S, De Vuyst P, van den Bosch JM, Rodriguez-Becerra E, Corvasce G, Lankhorst I, Sardina M, Montanari M, IFIGENIA Study Group: High-dose acetylcysteine in idiopathic pulmonary fibrosis. N Engl J Med 2005, 353:2229-2242.

303. Mackman N: The many faces of tissue factor. J Thromb Haemost 2009, 7: S136-S139.

304. Breitenstein A, Camici GG, Tanner FC: Tissue factor: beyond coagulation in the cardiovascular system. Clin Sci (Lond) 2009, 118:159-172.

305. Chambers RC: Procoagulant signaling mechanisms in lung inflammation and fibrosis: novel opportunities for pharmacological intervention? $\mathrm{Br} J$ Pharmacol 2008, 153:S367-S378.

306. Yasui H, Gabazza EC, Tamaki S, Kobayashi T, Hataji O, Yuda H, Shimizu S, Suzuki K, Adachi Y, Taguchi O: Intratracheal administration of activated protein $\mathrm{C}$ inhibits bleomycin-induced lung fibrosis in the mouse. Am J Respir Crit Care Med 2001, 163:1660-1668.

307. Juul K, Tybjaerg-Hansen A, Mortensen J, Lange P, Vestbo J, Nordestgaard BG: Factor V Leiden homozygosity, dyspnea, and reduced pulmonary function. Arch Intern Med 2005, 165:2032-2036.

308. Sode BF, Dahl M, Nielsen SF, Nordestgaard BG: Venous thromboembolism and risk of idiopathic interstitial pneumonia: a nationwide study. Am J Respir Crit Care Med 2010, 181:1085-1092.

309. Kotani I, Sato A, Hayakawa H, Urano T, Takada Y, Takada A: Increased procoagulant and antifibrinolytic activities in the lungs with idiopathic pulmonary fibrosis. Thromb Res 1995, 77:493-504.

310. Imokawa S, Sato A, Hayakawa H, Kotani M, Urano T, Takada A: Tissue factor expression and fibrin deposition in the lungs of patients with idiopathic pulmonary fibrosis and systemic sclerosis. Am J Respir Crit Care Med 1997, 156:631-636.

311. Wygrecka M, Kwapiszewska G, Jablonska E, Gerlach S, Henneke I, Zakrzewicz D, Guenther A, Preissner KT, Markart P: Role of Protease-activated Receptor-2 in Idiopathic Pulmonary Fibrosis. Am J Respir Crit Care Med 2011, 183:1703-1714.

312. Günther A, Mosavi P, Ruppert C, Heinemann S, Temmesfeld B, Velcovsky HG, Morr $H$, Grimminger F, Walmrath D, Seeger W: Enhanced tissue factor pathway activity and fibrin turnover in the alveolar compartment of patients with interstitial lung disease. Thromb Haemost 2000, 83:853-860

313. Bogatkevich GS, Gustilo E, Oates JC, Feghali-Bostwick C, Harley RA, Silver RM, Ludwicka-Bradley A: Distinct PKC isoforms mediate cell survival and DNA synthesis in thrombin-induced myofibroblasts. Am J Physiol Lung Cell Mol Physiol 2005, 288:L190-L201.

314. Mercer PF, Johns RH, Scotton CJ, Krupiczojc MA, Königshoff M, Howell DC, McAnulty RJ, Das A, Thorley AJ, Tetley TD, Eickelberg O, Chambers RC: Pulmonary epithelium is a prominent source of proteinase-activated receptor-1-inducible CCL2 in pulmonary fibrosis. Am J Respir Crit Care Med 2009, 179:414-425.

315. Kijiyama N, Ueno H, Sugimoto I, Sasaguri Y, Yatera K, Kido M, Gabazza EC, Suzuki K, Hashimoto E, Takeya H: Intratracheal gene transfer of tissue factor pathway inhibitor attenuates pulmonary fibrosis. Biochem Biophys Res Commun 2006, 339:1113-1119.

316. Howell DC, Goldsack NR, Marshall RP, McAnulty RJ, Starke R, Purdy G, Laurent GJ, Chambers RC: Direct thrombin inhibition reduces lung collagen, accumulation, and connective tissue growth factor mRNA levels in bleomycin-induced pulmonary fibrosis. Am J Pathol 2001, 159:1383-1395.

317. Günther A, Lübke N, Ermert M, Schermuly RT, Weissmann N, Breithecker A, Markart P, Ruppert C, Quanz K, Ermert L, Grimminger F, Seeger W: Prevention of bleomycin-induced lung fibrosis by aerosolization of heparin or urokinase in rabbits. Am J Respir Crit Care Med 2003, 168:1358-1365.

318. Eitzman DT, McCoy RD, Zheng X, Fay WP, Shen T, Ginsburg D, Simon RH: Bleomycin-induced pulmonary fibrosis in transgenic mice that either lack or overexpress the murine plasminogen activator inhibitor-1 gene. J Clin Invest 1996, 97:232-237.

319. Trejo J, Connolly AJ, Coughlin SR: The cloned thrombin receptor is necessary and sufficient for activation of mitogen-activated protein kinase and mitogenesis in mouse lung fibroblasts. Loss of responses in fibroblasts from receptor knockout mice. J Biol Chem 1996, 271:21536-21541.

320. Bogatkevich GS, Tourkina E, Silver RM, Ludwicka-Bradley A: Thrombin differentiates normal lung fibroblasts to a myofibroblast phenotype via the proteolytically activated receptor- 1 and a protein kinase Cdependent pathway. J Biol Chem 2001, 276:45184-45192.

321. Blanc-Brude OP, Chambers RC, Leoni P, Dik WA, Laurent GJ: Factor Xa is a fibroblast mitogen via binding to effector-cell protease receptor- 1 and autocrine release of PDGF. Am J Physiol Cell Physiol 2001, 281:C681-C689.

322. Ohba T, McDonald JK, Silver RM, Strange C, LeRoy EC, Ludwicka A: Scleroderma bronchoalveolar lavage fluid contains thrombin, a mediator of human lung fibroblast proliferation via induction of platelet-derived growth factor alpha-receptor. Am J Respir Cell Mol Biol 1994, 10:405-412.

323. Hernández-Rodríguez NA, Cambrey AD, Harrison NK, Chambers RC, Gray AJ, Southcott AM, duBois RM, Black CM, Scully MF, McAnulty RJ: Role of thrombin in pulmonary fibrosis. Lancet 1995, 346:1071-1073.

324. Chambers RC, Dabbagh K, McAnulty RJ, Gray AJ, Blanc-Brude OP, Laurent GJ: Thrombin stimulates fibroblast procollagen production via proteolytic activation of protease-activated receptor 1. Biochem J 1998, 333:121-127.

325. Blanc-Brude OP, Archer F, Leoni P, Derian C, Bolsover S, Laurent GJ, Chambers RC: Factor $\mathrm{Xa}$ stimulates fibroblast procollagen production, proliferation, and calcium signaling via PAR1 activation. Exp Cell Res 2005, 304:16-27.

326. Jenkins RG, Su X, Su G, Scotton CJ, Camerer E, Laurent GJ, Davis GE, Chambers RC, Matthay MA, Sheppard D: Ligation of protease-activated receptor 1 enhances alpha(v)beta6 integrin-dependent TGF-beta activation and promotes acute lung injury. J Clin Invest 2006, 116:1606-1614.

327. Suzuki T, Moraes TJ, Vachon E, Ginzberg HH, Huang TT, Matthay MA, Hollenberg MD, Marshall J, McCulloch CA, Abreu MT, Chow CW, Downey 
GP: Proteinase-activated receptor-1 mediates elastase-induced apoptosis of human lung epithelial cells. Am J Respir Cell Mol Biol 2005, 33:231-247.

328. Markart P, Nass R, Ruppert C, Hundack L, Wygrecka M, Korfei M, Boedeker RH, Staehler G, Kroll H, Scheuch G, Seeger W, Guenther A: Safety and tolerability of inhaled heparin in idiopathic pulmonary fibrosis. $J$ Aerosol Med Pulm Drug Deliv 2010, 23:161-172.

329. Kubo H, Nakayama K, Yanai M, Suzuki T, Yamaya M, Watanabe M, Sasaki H: Anticoagulant therapy for idiopathic pulmonary fibrosis. Chest 2005, 128:1475-1482.

330. Moore BB, Hogaboam CM: Murine models of pulmonary fibrosis. Am J Physiol Lung Cell Mol Physiol 2008, 294:L152-L160.

331. Chua F, Gauldie J, Laurent GJ: Pulmonary fibrosis: searching for model answers. Am J Respir Cell Mol Biol 2005, 33:9-13.

doi:10.1186/1755-1536-5-11

Cite this article as: Todd et al: Molecular and cellular mechanisms of pulmonary fibrosis. Fibrogenesis \& Tissue Repair 2012 5:11.

\section{Submit your next manuscript to BioMed Central and take full advantage of:}

- Convenient online submission

- Thorough peer review

- No space constraints or color figure charges

- Immediate publication on acceptance

- Inclusion in PubMed, CAS, Scopus and Google Scholar

- Research which is freely available for redistribution 